\title{
The mid-Langhian flooding in the eastern Central Paratethys: integrated stratigraphic data from the Transylvanian Basin and SE Carpathian Foredeep
}

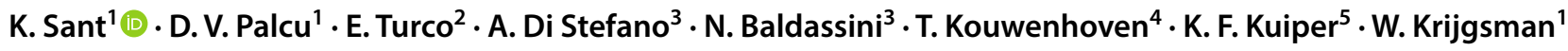

Received: 9 September 2018 / Accepted: 13 July 2019 / Published online: 10 August 2019

(c) The Author(s) 2019

\begin{abstract}
The mid-Langhian ("Badenian") flooding fully reconnected the semi-isolated Central Paratethys realm with the Mediterranean and, thereby, drastically changed the middle Miocene paleogeography of Central Europe. Due to the scattered stratigraphic record and scarcity of independent age constraints in some areas, the precise age and underlying mechanism are still debated. We present integrated chronostratigraphic data from five sections in the eastern part of the system to reconstruct the flooding event distal from the strait to the Mediterranean. By applying modern Mediterranean biochronology (planktonic foraminifera and calcareous nannofossils), supplemented by an ${ }^{40} \mathrm{Ar} /{ }^{39} \mathrm{Ar}$ age on a tuff, we demonstrate that the widespread open marine settings in the NW Transylvanian Basin were definitely installed after 14.9 Ma (MMi4d biozone), and in most areas before 14.4 Ma. In the marginal study area in the SE Carpathian Foredeep, fully marine conditions likely set in slightly later (14.6-14.4 Ma). There, short-lived marine incursions into the brackish environment occurred since the latest Burdigalian ("pre-flooding phase"). The new ages overlap with the flooding in the majority of the Central Paratethys ( 14.9-14.4 Ma), and with marine overflow into the Black Sea (14.85 Ma). We suggest that the transgression was driven by subsidence of the Pannonian Basin, by creating accommodation space and diminishing barriers between sub-basins, but was likely enhanced by a global sea-level rise. Finally, we speculate that the scarcity of all calcareous material in the SE Carpathian Foredeep before the mid-Langhian flooding might be related to pulses of nutrient-rich brackish and low $\mathrm{pH}$ water from the neighboring Black Sea Basin.
\end{abstract}

Keywords Integrated stratigraphy $\cdot$ Radioisotopic dating $\cdot$ Foraminifera $\cdot$ Nannofossils $\cdot$ Miocene paleogeography

\section{Introduction}

Electronic supplementary material The online version of this article (https://doi.org/10.1007/s00531-019-01757-z) contains supplementary material, which is available to authorized users.

K. Sant

karin.sant@gmail.com

1 Paleomagnetic Laboratory Fort Hoofddijk, Utrecht University, Utrecht, The Netherlands

2 Department of Chemistry, Life Sciences and Environmental Sustainability, Parma University, Parma, Italy

3 Department of Biological, Geological and Environmental Sciences, Catania University, Catania, Italy

4 Department of Earth Sciences, Stratigraphy-Paleontology, Utrecht University, Utrecht, The Netherlands

5 Department of Earth Sciences, Vrije Universiteit Amsterdam, Amsterdam, The Netherlands
During the Miocene, a large part of Central Europe was covered by the Paratethys Sea (Popov et al. 2004; Rögl 1998). In this period, active geodynamic processes, such as the opening of the Pannonian back-arc system, exhumation of the Alps-Carpathians-Dinarides orogens and associated volcanic episodes and opening/closure of sea straits resulted in a dynamic paleogeography (e.g., Fodor et al. 1999; Pécskay et al. 2006; Kováč et al. 2017b; Matenco 2017). As a result, the paleoenvironments of the Central Paratethys basins shifted between open marine, brackish and lacustrine settings (de Leeuw 2011; Piller et al. 2007; Rögl 1998), and its sedimentary record reflects changes in tectonics, eustatics, climate and basin connectivity (Kováč et al. 2017a; Palcu et al. 2015).

Correlating the Paratethys strata to regional and global events, however, is often challenging, because the 
stratigraphic scheme of the Central Paratethys consists of regional stages that are generally based on endemic fossil assemblages and correlations to sequence stratigraphic records (Haq et al. 1987; Hardenbol et al. 1998; Hilgen et al. 2012). Nevertheless, numerous independent age constraints have been produced by integrated stratigraphic methods in the last decade (e.g., Mandic et al. 2012; de Leeuw et al. 2013; Palcu et al. 2015; Sant et al. 2018). These allowed quantitative reconstructions of major tectonic and climatic events affecting the whole area, such as the Badenian Salinity Crisis (de Leeuw et al. 2010), the Badenian-Sarmatian Extinction Event (Harzhauser and Piller 2004; Palcu et al. 2015) and late Miocene installation of Lake Pannon (Filipescu et al. 2011; Magyar et al. 1999; ter Borgh et al. 2013; Vasiliev et al. 2010).

Progress was also made in constraining the timing of the widespread marine "Badenian" transgression (middle Miocene) of the Pannonian Basin and Carpathian Foredeeps (Bukowski et al. 2018; Ćorić et al. 2009; Hohenegger et al. 2009; Kovác et al. 2017a, 2018; Selmeczi et al. 2012). A two-step flood has been proposed (Kovác et al. 2007, 2017a): a first Badenian flooding, occurring in the early Langhian, and second flooding, occurring in the middle Langhian. The first flooding only had a small impact on the Central Paratethys-installing semi-marine environments with occasional marine fauna influxes. The Slovenian corridor probably functioned as the connecting sea strait (Bistricic and Jenko 1985; Sant et al. 2017). Central Europe became covered by a very diverse marine-brackish-lacustrine system (Brzobohatý et al. 2003; Kovac et al. 2003; Mandic et al. 2012; Rijavec 1985; Zuschin et al. 2014) (Fig. 1b).

The second Badenian flooding turned the Central Paratethys into an open marine gulf of the Mediterranean, by increasing the connection through the Slovenian strait (Brzobohatý et al. 2007; Kováč et al. 2007; Rögl 1998) (Fig. 1a). This event also impacted the Eastern Paratethys, where a short-lived marine episode, the Tarkhanian marine flooding, took place at around 14.85 Ma (Palcu et al. 2017). The onset of the widespread open marine "Badenian Sea", associated with the second Badenian flooding, is recognized by an abrupt shift to finer-grained sediments enriched in Langhian microfossils, most importantly planktonic foraminifera Praeorbulina glomerosa and Orbulina suturalis (Kováč et al. 2017a; Sant et al. 2017), and in most regions, nannofossils of the NN5 (Martini 1971) biozone (Papp et al. 1978; Kováč et al. 2007 and references therein) (Table 1). Following the most recent low latitude (Mediterranean) biochronology (Table 1), these Langhian marker fossils suggest a maximum age of $\sim 15.3 \mathrm{Ma}$ for the second Badenian flooding that installed the open marine Badenian Sea (Kováč et al. 2017a; Sant et al. 2017).

The timing and paleoenvironmental changes during the Badenian floodings in the Romanian Carpathian Foredeep and Transylvanian Basin (4 and 6 in Fig. 1) are still unclear. These basins are key areas to reconstruct the effect of these floodings far away from the Slovenian strait and proximal to the Eastern Paratethys (Black Sea basin) strait.

The scarcity of integrated chronostratigraphic data, outdated terminology and/or contradicting interpretations hamper a proper reconstruction of the late Burdigalian-Langhian stratigraphy in the Romanian basins. For instance, the flooding boundary in the Transylvanian Basin is commonly placed at $\sim 16 \mathrm{Ma}$, whereas directly overlying tuffs (Dej tuff) are dated to be $~ 14.4$ Ma (Szakács et al. 2012; de Leeuw et al. 2013; Beldean et al. 2013). Traditionally,

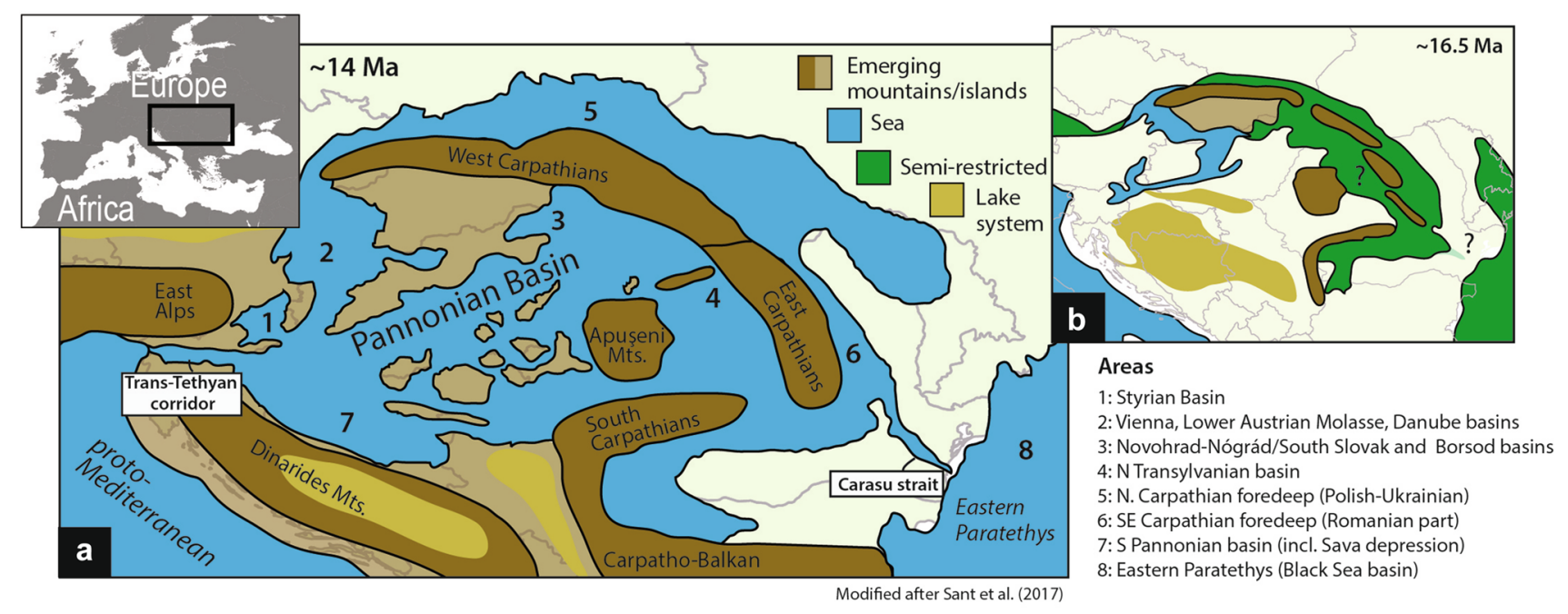

Fig. 1 Simplified facies maps of the Badenian Sea (a) and pre-flooding phase (late Burdigalian) (b). Key areas are numbered. Modified after Sant et al. (2017) 
Table 1 Dated planktonic foraminifera and calcareous nannofossils (bold) marker events for the oceanic and Mediterranean biostratigraphic schemes

\begin{tabular}{|c|c|c|c|c|c|}
\hline \multicolumn{6}{|c|}{ Oceanic biozones } \\
\hline \multicolumn{2}{|c|}{ Basal marker } & \multirow{2}{*}{$\begin{array}{l}\text { Biozone } \\
\text { CNM8 }\end{array}$} & \multirow{2}{*}{$\begin{array}{l}\text { Author (zone) } \\
\text { Backman et al. (2012) }\end{array}$} & \multirow{2}{*}{$\begin{array}{l}\text { Age }(\mathrm{Ma}) \\
\mathbf{1 3 . 5 3}\end{array}$} & \multirow{2}{*}{$\begin{array}{l}\text { Author (Age) } \\
\text { Backman et al. (2012) }\end{array}$} \\
\hline LO & S. heteromorphus & & & & \\
\hline FO & F. robusta & M9b & Wade et al. (2011) & 13.13 & Lourens et al. (2004) \\
\hline FO & F. fohsi & M9a & Wade et al. (2011) & 13.41 & Lourens et al. (2004) \\
\hline FO & F."praefohsi" & M8 & Wade et al. (2011) & 13.77 & Lourens et al. (2004) \\
\hline FO & F. peripheroacuta & M7 & Wade et al. (2011) & 14.24 & Lourens et al. (2004) \\
\hline FO & O. suturalis & M6 & Wade et al. (2011) & 15.10 & Wade et al. (2011) \\
\hline FO & D. signus & CNM7 & Backman et al. (2012) & 15.73 & Backman et al. (2012) \\
\hline FO & P. glomerosa s.s. & M5b & Wade et al. (2011) & 16.27 & Lourens et al. (2004) \\
\hline FO & P. sicana & M5a & Wade et al. (2011) & 16.38 & Wade et al. (2011) \\
\hline FO & F. birnageae & M4b & Wade et al. (2011) & 16.69 & Wade et al. (2011) \\
\hline LO & C. dissimilis & M4a & Wade et al. (2011) & 17.54 & Lourens et al. (2004) \\
\hline FO & S. heteromorphus & CNM6 & Backman et al. (2012) & 17.75 & Backman et al. (2012) \\
\hline FO & T. carinatus & NN3 & Martini (1971) & 19.18 & Pälike et al. (2005) \\
\hline LO & S. belemnos & NN4 & Martini (1971) & 17.94 & Backman et al. (2012) \\
\hline LO & H. ampliaperta & NN5 & Martini (1971) & 14.86 & Curry et al. (1995) \\
\hline LO & S. heteromorphus & NN6 & Martini (1971) & 13.53 & Backman and Raffi (1997) \\
\hline \multicolumn{6}{|c|}{ Mediterranean biozones } \\
\hline LO & G. peripheroronda & MMi6 & Iaccarino AND Salvatorini (1982) & 13.52 & Mourik et al. (2011) \\
\hline LCO & S. heteromorphus & MNN6a & $\begin{array}{l}\text { Fornaciari et al. (1996) emended Di Stefano et al. } \\
\text { (2008) }\end{array}$ & 13.65 & Lourens et al. (2004) \\
\hline $\mathrm{FO}$ & G. praemenardii & MMi5c & Iaccarino and Salvatorini (1982) & 13.92 & Abdul Aziz et al. (2008) \\
\hline FCO & H. walbersdorfensis & MNN5c & $\begin{array}{l}\text { Fornaciari et al. (1996) emended Di Stefano et al. } \\
\text { (2008) }\end{array}$ & 14.05 & Abdul Aziz et al. (2008) \\
\hline LCO & H. waltrans & MNN5b & Di Stefano et al. (2008) & 14.36 & Abdul Aziz et al. (2008) \\
\hline $\mathrm{FO}$ & O. universa & MMi5b & Iaccarino and Salvatorini (1982) & 14.36 & Abdul Aziz et al. (2008) \\
\hline $\mathrm{FO}$ & O. suturalis & MMi5a & Cita and Premoli Silva (1971-1973) & 14.56 & Abdul Aziz et al. (2008) \\
\hline $\mathrm{FO}$ & P. gl. circularis & MMi4d & Iaccarino and Salvatorini (1982) & 14.89 & Abdul Aziz et al. (2008) \\
\hline $\mathrm{FO}$ & P. gl. curva & $\mathrm{MMi} 4 \mathrm{c}$ & Di Stefano et al. (2008) & 15.34 & Turco et al. (2017) \\
\hline PE & S. heteromorphus & MNN5a & Di Stefano et al. (2008) & 15.37 & Turco et al. (2017) \\
\hline $\mathrm{AaB}$ & P. siakensis & MMi4b & Di Stefano et al. (2008) & 15.48 & Turco et al. (2017) \\
\hline PB & S. heteromorphus & MNN4c & $\begin{array}{l}\text { Fornaciari et al. (1996) emended Di Stefano et al. } \\
\text { (2008) }\end{array}$ & 15.74 & Turco et al. (2017) \\
\hline LCO & H. ampliaperta & MNN4b & $\begin{array}{l}\text { Fornaciari et al. (1996) emended Di Stefano et al. } \\
\text { (2008) }\end{array}$ & 16.09 & Turco et al. (2017) \\
\hline $\mathrm{FO}$ & G. sicanus (3 apertures) & MMi4a & $\begin{array}{l}\text { Iaccarino and Salvatorini (1982) emended Iaccarino et al. } \\
\text { (2011) }\end{array}$ & 16.18 & Turco et al. (2017) \\
\hline LO & C. dissimilis & MMi3 & Iaccarino and Salvatorini (1982) & 17.54 & Lourens et al. (2004) \\
\hline FCO & S. heteromorphus & MNN4a & Di Stefano et al. (2008) & 17.99 & Foresi et al. (2014) \\
\hline LCO & S. belemnos & MNN3b & Fornaciari and Rio (1996) & 18.44 & Foresi et al. (2014) \\
\hline FCO & S. belemnos & MNN3a & Fornaciari and Rio (1996) & 19.05 & Foresi et al. (2014) \\
\hline
\end{tabular}

Mediterranean calcareous plankton assemblages differ from the Atlantic low-latitude ones from the middle Miocene onwards, so their bio-events have significantly different ages (see also Di Stefano et al. 2008, 2015; Foresi et al. 2011; Iaccarino et al. 2011; Turco et al. 2002)

Calcareous nannoplankton marker species are marked bold

$F O$ first occurrence, $F C O$ first common occurrence, $L O$ last occurrence, $L C O$ last common, occurrence, $P B$ paracme beginning, $P E$ paracme end, $A a B$ acme a base

sediments positioned below the open marine Langhian strata are assigned to the Burdigalian stage, but in some cases part of these underlying sediments turned out to have a younger age corresponding to the early Langhian (Mărunţeanu 1999; Melinte-Dobrinescu and Stoica 2014; Orbocea et al. 1986a; Rabagia and Maţenco 1999; Sant et al. 
2017). Paleontological studies commonly use the regional Paratethys taxonomy, which is difficult to compare to the Mediterranean and/or low latitude taxonomy. In addition, the use of ambiguous formation names and/or regional fossil assemblages may result in a variable and contradictory correlations (Melinte-Dobrinescu and Stoica 2014; Săndulescu 1988; Mărunţeanu 1999; Beldean et al. 2012; de Leeuw et al. 2013; Székely et al. 2016). All of the factors above complicate correlation of the stratigraphy from different regions to each other, and to the global time scale (Paucă 1976; Krézsek and Bally 2006 and references therein; Beldean et al. 2013; Gozhyk et al. 2015; Holcová et al. 2018; Kováč et al. 2018) hampering paleogeographic and paleoenvironmental reconstructions of the whole Central Paratethys system.

Here, we reconstruct the timing and environmental changes of the Langhian (Badenian) transgression in the Transylvanian Basin and SE Carpathian Foredeep by integrating magnetostratigraphic and radioisotopic data with biostratigraphic results. We apply the most recent Mediterranean biochronology for calcareous nannofossils (MNNzones of Fornaciari and Rio 1996; Di Stefano et al. 2008; Iaccarino et al. 2011) and planktonic foraminifera (MMizones of Di Stefano et al. 2008; Iaccarino et al. 2007, 2011) for dating (Table 1). This approach usually results in younger ages compared to studies using oceanic biozones and biochronology (Sant et al. 2017). Furthermore, we will investigate the role that marine straits, eustatic fluctuations and tectonic changes play in the distribution of the marine system by integrating the new data with (bio)stratigraphic and paleogeographic results from other Paratethys localities.

\section{Geological background}

\section{Basins and mountains of the Pannonian-Carpathian region}

The Pannonian back-arc basin formed in response to the rapid rollback of a Carpathian slab attached to 'stable Europe' during the Miocene ( 18-9 Ma) (e.g., Fodor et al. 1999; Horvath et al. 2006; Matenco and Radivojević 2012). In the Pannonian Basin, a chain of (half-)grabens formed during a diachronous rifting phase with a peak in the middle Miocene (Balázs et al. 2016; Nagymarosy and Hámor 2012; Tari et al. 1992). In the eastern part (Tisza-Dacia terranes), the extensional process lasted until the late Miocene (Balázs et al. 2016).

The Transylvanian Basin was a satellite basin of the Pannonian basin since the Miocene (4 in Fig. 1) and is at present surrounded by the Apuseni mountains and E, SE and S Carpathians. The majority of the Miocene sediments is situated on top of the Tisza-Dacia terrane (Schmid et al.
2008; Ustaszewski et al. 2008). In the lower Miocene, it was a flexural foredeep basin created by the emplacement of the Pienides thrust nappes over the northern edge of the Transylvanian embayment (Krézsek and Bally 2006; Tischler et al. 2008). In contrast to the Pannonian Basin, the majority of middle-late Miocene subsidence in the Transylvanian Basin was most likely driven by a deep (thermal) lithospheric mechanism, and only a fraction of the sediment infill is associated with early middle Miocene crustal faults (Tiliţă et al. 2013 and references therein). The eastern flank of the Transylvanian Basin is covered by a thick pile of MiocenePliocene volcanics (Mason et al. 1998; Szabó et al. 1992). At present, the basin is the most important province for gas production in Romania and its surroundings (Ciulavu et al. 2000).

The East Carpathian Foredeep circumvents the eastern and south-eastern flanks of the E and SE Carpathians (6 in Fig. 1). Neritic (relatively deep) marine deposition took place in the ESE foredeep close to the Carpathian thrust front (Tărăpoancă 2003). Lower to middle Miocene sediments accumulated in shallow-marine to fluvio-deltaic settings in piggyback basins (Săndulescu et al. 1995), or in grabens between gradually uplifting Carpathian blocks (Matenco et al. 2010; Mirăuţa 1967; Olteanu 1951). At present, most lower-middle Miocene sediments are incorporated into thrust and fold belts of the external nappes. A total shortening of $\sim 160-220 \mathrm{~km}$ was accommodated in the East, SE and South Carpathians by thick- and thin-skinned nappe stacking during Cretaceous-Miocene moments of subduction (Morley 2003; Roure et al. 1993). Thermochronological studies infer that most of the topographic relief of the $\mathrm{E}$ and SE Carpathians formed during Miocene times $(\sim 15-11 \mathrm{Ma})$, whereas the bulk exhumation in the South Carpathians occurred during the late Cretaceous-Paleogene (Matenco 2017; Merten 2011). The Apuseni mountains were most likely almost completely exhumed since Oligocene times (e.g., Merten et al. 2011; Kounov and Schmid 2013; Reiser et al. 2017). Eventual Miocene uplift must have been below $1 \mathrm{~km}$ (Matenco 2017).

Connectivity between the Transylvanian Basin, Carpathian Foredeep and Pannonian Basin is uncertain due to the removal of Miocene sediments during the uplift of the Carpathians, the burial of lower-middle Miocene strata under volcanic rocks, and a general lack of age constraints. Connections between the Transylvanian Basin and the SE Carpathian Foredeep likely existed at least until Langhian times (Matenco 2017; Merten 2011; Tărăpoancă 2003), because patches of such Langhian sediments are nowadays found in the Carpathian mountains (Codarcea et al. 1968). 


\section{Early middle Miocene stratigraphy of the Romanian Paratethys}

In the regional Central Paratethys time scale, the lower Miocene is subdivided into the Egerian, Eggenburgian, Ottnangian and Karpatian stages (Cicha and Rögl 2003; Hilgen et al. 2012; Papp and Cicha 1978; Piller et al. 2007). The middle Miocene is divided into the Badenian and Sarmatian stages (Papp and Cicha 1978; Papp and Steininger 1974) (Fig. 2). Local stages are used in many Romanian maps and old literature. This can be confusing since the terms Chattian-Burdigalian (ch-bu), Helvetian (he) and Tortonian (to) are roughly referring to the late Oligocene-early Miocene, Burdigalian-earliest Langhian, and early middle Miocene time intervals, respectively (e.g., Ilie 1951; Marinescu and Peltz 1967). In this manuscript, we only use the term Burdigalian (20.4-16.1 Ma) sensu Hilgen et al. (2012).

\section{Stratigraphy of the Romanian East Carpathian Foredeep}

A significant portion of the lower-middle Miocene strata of the Romanian East Carpathian Foredeep is incorporated into the Tarcău, Vrancea and Subcarpathian Carpathian nappes (so-called external nappes) (Juravle 2010; Mărunţeanu 1999; Săndulescu et al. 1980). The large variety in sedimentary settings resulted in a wide array of formations with different thicknesses in different areas. Figure 2 depicts the generalized stratigraphy for two areas in the Romanian East Carpathian Foredeep, namely for the most external nappe (Subcarpathian), and for a more restricted piggyback basin in the SE Carpathian bend area. Detailed stratigraphic background data can be found in Supplementary Data A and Sant et al. (2019).

In general, the lower Miocene stratigraphy begins with an evaporitic package followed by sands, silts and marls. The subsequent grey schlier formation is dominated by marls with silt and sand interbeds and a few tuff horizons (e.g., Ioniţă 1962; Marunteanu 1999). In most areas, a significant evaporitic interval (10-25 m thick; Perchiu gypsum) is noted in the basal part (Mărunţeanu 1999), while gypsum levels are common in the uppermost grey schlier Fm as well (Mărunţeanu 1999; Săndulescu et al. 1980). In the SE Carpathian bend area, the more or less time equivalent strata are termed the Doftana Fm (Săndulescu et al. 1995; Stefanescu et al. 2006) (Fig. 2). The marginal areas of the SE Carpathian Foredeep, such as the SE Carpathian Bend area are represented mostly by shallow marine-to-brackish environments with tiny and fragile marine microfossils and occurrences of ostracods and characean algae indicating fluctuating salinities. Orbocea et al. (1986b) suggest salinities comparable to the present-day Black Sea ( 18 PSU).

The lower parts of the Grey Schlier and Doftana Fms (i.e. the pre-flooding sediments) are attributed to the NN4 calcareous nannofossils biozone (Martini 1971) corresponding to the lower Miocene portion of the uppermost CNM5 and CNM6 zones (Backman et al. 2012) (Table 1). Their upperparts are characterized by scarce $P$. glomerosa and/or $O$. suturalis and nannofossils of the NN5 Biozone, testifying of a middle Miocene (Langhian) age for their upper parts (Mărunţeanu 1999; Orbocea et al. 1986a; Săndulescu et al. 1995; Ştefănescu and Mărunteanu 1980).

The base of the Badenian flooding is clearly visible by a shift to marls with a rich Langhian planktonic foraminiferal assemblage (Globigerina Marls). Above, the marls are intercalated with ash layers of the Slănic Tuff, that range from 0.2 to $3 \mathrm{~m}$ in thickness (rarely up to $\sim 100 \mathrm{~m}$ ) (Mărunţeanu 1999; Săndulescu et al. 1995). The Slănic tuff is chemically correlated to the Dej tuff in the Transylvanian Basin and the Novoselits-Danilov tuff in the Ukrainian Carpathian Foredeep (Pishvanova 1969) but was never dated by isotopic methods. The overlying Upper Salt Formation, with its base at the Langhian-Serravallian boundary, testifies of the Badenian Salinity Crisis (de Leeuw et al. 2010; Túnyi et al. 2005) and correlates to the Transylvanian salts. It is characterized by evaporitic lithologies in various forms, including salt breccia within marls, sands, halite among black shales and packages of gypsum (Peryt 2006).

\section{Stratigraphy of the N Transylvanian Basin}

The lower Miocene marine (to semi-restricted) sediments in the Transylvanian Basin thicken northwards towards the Pienides nappes (Ciulavu et al. 2000; Krézsek and Bally 2006; Tischler 2005). The southern Transylvanian Basin was dominated by marginal marine and continental sediments (Ilie 1955; Krézsek et al. 2010). The lower Miocene succession is mainly represented by the Vima, Coruş, Chechiş and Hida formations having highly diachronous boundaries and reflecting deep to shallow basinal settings (Filipescu 2011; Krézsek and Bally 2006) (Fig. 2). In the last decade, a series of high-resolution biostratigraphic studies has been carried out (Beldean et al. 2010, 2012, 2013; de Leeuw et al. 2013; Filipescu and Beldean 2007; Filipescu and Silye 2008; Székely et al. 2016, 2017). More detailed stratigraphic background data is found in Supplementary Data A and Sant et al. (2019).

The pre-flooding sediments of the Hida Fm (Hofmann 1879; Koch 1900) represent a relatively deep phase of the pre-Badenian basin that is followed by a gradual shallowing from slope to proximal delta fan environment. Siliciclastic deposits dominate and range from turbidites yielding diverse planktonic and benthic foraminifera to coarse-grained delta fans in the top with agglutinated foraminifera and small planktonic foraminifera (Beldean et al. 2012; Iva et al. 1971; Popescu and Brotea 1994; Székely et al. 2016). An Aquitanian-Burdigalian age was 


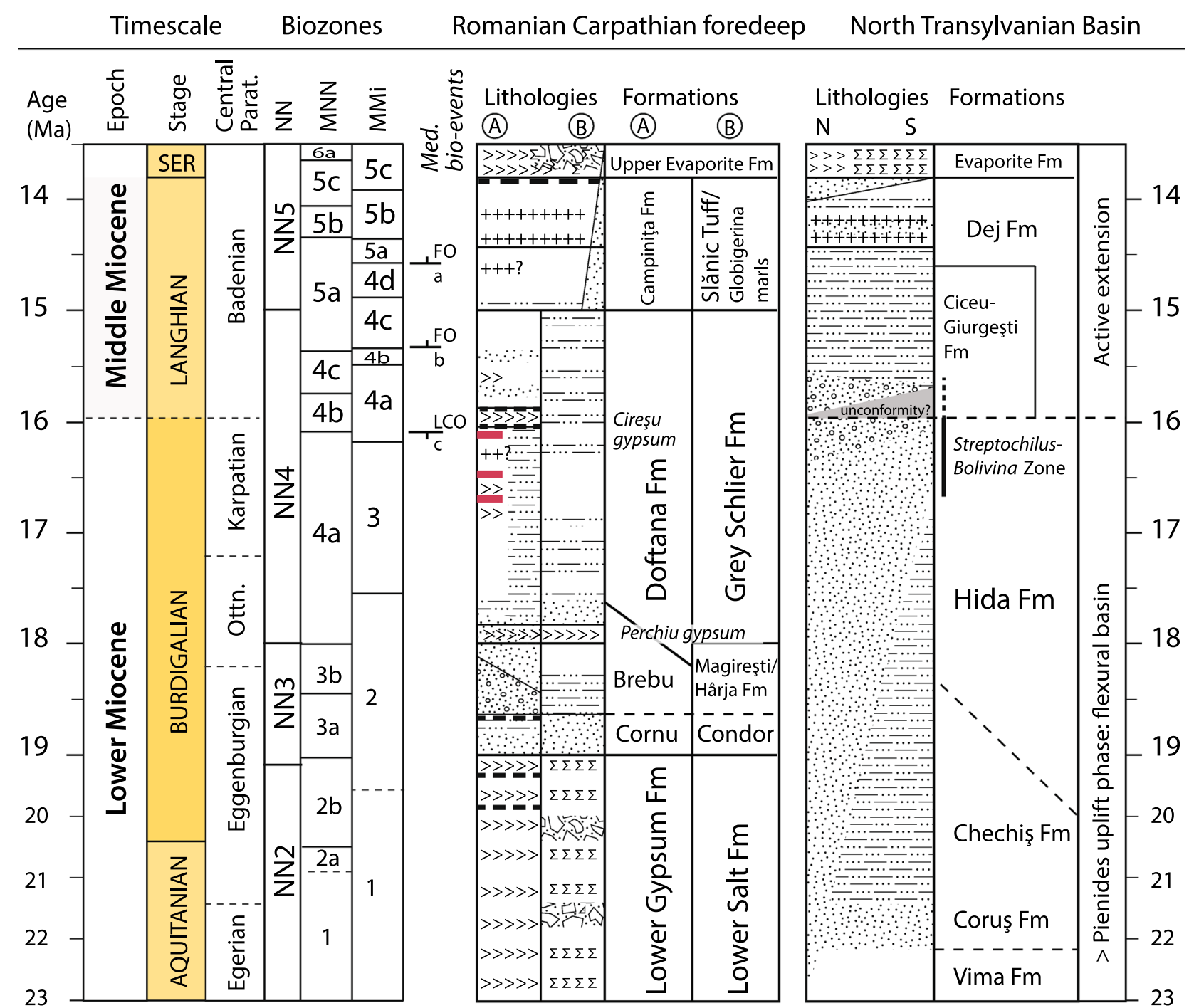

Dominant lithologies

\begin{tabular}{|c|c|}
\hline$\therefore \cdots$ & Shale with sands \\
\hline $\begin{array}{l}>>> \\
>>3\end{array}$ & Gypsum \\
\hline & Black shale levels \\
\hline
\end{tabular}

Bio-events a. O. suturalis, b. P. glomerosa, c. H. ampliaperta

\section{Sandstone \\ Salt \\ Oxidized \\ clay levels}
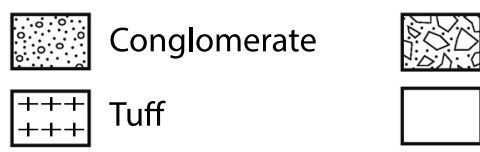

Breccia
(A) SE Carpathian Bend area (shallow)
(B) Romanian East Carpathian foredeep (deep)

Fig. 2 An updated compilation of lower-middle Miocene stratigraphy and common formation names for the Romanian East Carpathian Foredeep (after Ioniţă 1962; Mărunţeanu 1999; Sandulescu et al. 1980; Săndulescu et al. 1995) and north Transylvanian Basin (Krézsek and Bally 2006 and references therein). Note that the most recent low latitude (Mediterranean) biochronology is used to construct the age framework. The global and regional stages in the timescale are taken after Hilgen et al. (2012). The Mediterranean biozones and Atlantic NN-biozones are displayed for reference (see Table 1 for all references). The lower Miocene Fms in the Transylvanian Basin are diachronous and poorly dated, therefore, formation boundaries cannot be drawn. The Dej and Slănic tuffs have many synonyms, a.o., Perşani tuff in the SE Transylvanian Basin (Rado et al. 1980), Racos tuff in the E Transylvanian Basin, Nereju tuff in the SE Carpathian Foredeep (Ioniţă 1962), Govora tuff in the South Carpathians, and Novoselits-Danilov tuff in the Ukrainian Foredeep (Pishvanova 1969). The Evaporite Fm (Ciupagea et al. 1970; Dragoş 1969; Paucă 1976; Stoica and Gherasie 1981) is also known as the Ocna Dejului Fm in the NW Transylvanian Basin (Mészáros 1991). In the easternmost Foredeep the lowermost Grey Schlier Fm is known as the Teşcani Fm (Mărunţeanu, 1999) but in other literature and/or regions it may refer to other intervals (Mirăuţa 1967; Sandulescu et al. 1980, 1995). The term "Poiana marls" is used for the uppermost Magireşti Fm (Mărunţeanu 1999; Olteanu 1951) 
determined for the Hida Fm based on calcareous nannofossils marking the NN2-NN4 biozonal interval (Table 1; Fig. 2) (e.g., Mészáros 1991; Beldean et al. 2010, 2012). The uppermost Hida Fm is in many locations characterized by shallow coastal facies (e.g., Beldean et al. 2013). An unconformity is suggested at the top of the Hida Fm in the majority of the basins, which is most pronounced in the central and southern part (Krézsek and Bally 2006).

In some sections in the $\mathrm{N}$ Transylvanian Basin, an interval with a bloom in small-sized ( $63 \mu \mathrm{m}$ fraction) biserial foraminifer Streptochilus was recorded in the top of the Hida Fm just below the Dej Fm (Beldean et al. 2013). Beldean et al. (2010) proposed to name it the Streptochilus-Bolivina Abundance Zone. Similar blooms occurred in the Atlantic and Indian oceans between 19 and $17 \mathrm{Ma}$, and are attested to the upwelling of cold nutrient-rich water or eutrophic conditions (Smart and Thomas 2006). Beldean et al. (2013) proposed that the Streptochilus-Bolivina Abundance Zone could have a similar age.

The Dej Formation is associated with a new transgression and the instalment of the widespread Badenian Sea (Kováč et al. 2017a; Sant et al. 2017). The basin axis migrated southwards, so the deposits cover a large area (Filipescu 1996; Krézsek et al. 2010; Popescu 1970). It is represented by a $\sim 50-150 \mathrm{~m}$ thick carbonatic and siliciclastic package bearing a rich foraminiferal assemblage with Praeorbulina glomerosa at the base (Popescu 1970), followed by the appearance of Orbulina suturalis. These typical middle Miocene (Langhian) foraminiferas first occur in the Mediterranean at $15.34 \mathrm{Ma}(P$. gl. curva; P. gl. glomerosa is dated at $15.15 \mathrm{Ma}$ ) and $14.56 \mathrm{Ma}$, respectively, following the most recent Mediterranean biochronology (Table 1). At the western basin margin, bioclastic limestones are common (Filipescu and Gîrbacea 1997; Paucă 1951). The middle part of the Dej Fm contains tuffs, tuffites and volcanoclastic material of the Dej tuff complex, derived from a phase of explosive volcanism in the intra-Carpathians (Moisescu and Popescu 1967; Seghedi et al. 2004; Seghedi and Szakacs 1991). Its thickness varies between 1 and $120 \mathrm{~m}$ (Szakács et al. 2012). The tuff serves as an important marker of the basal middle Miocene succession because it is well visible in the field and in seismic profiles. Various authors dated the Dej tuff by ${ }^{40} \mathrm{Ar} /{ }^{39} \mathrm{Ar}, \mathrm{K}-\mathrm{Ar}$, zircon fission track and (U-Th)/He methods, resulting in a wide age range between $\sim 16$ and $13 \mathrm{Ma}$ (Nicolescu and Mârza 2010; Seghedi and Szakacs 1991; Szakács et al. 2012). The most recent and most consistent ages are known from ${ }^{40} \mathrm{Ar} /{ }^{39} \mathrm{Ar}$ dating, providing ages of $14.38 \pm 0.06$ and $14.37 \pm 0.06 \mathrm{Ma}$ in the NW Transylvanian Basin (de Leeuw et al. 2013). The uppermost sediments of the Dej Fm are usually marine marls that were deposited deeper than $100 \mathrm{~m}$ (Filipescu 2011).

The Dej Fm is overlain by salt and gypsum that can be traced all over the Transylvanian basin (e.g., Ciupagea et al.
1970; Krézsek and Bally 2006). This phase reflects the Badenian Salinity crisis, a well-documented event in the Central Paratethys, of which the onset was radioisotopically dated at 13.8 Ma (Báldi et al. 2017; de Leeuw et al. 2010; Hryniv et al. 2007; Peryt 2000; Túnyi et al. 2005).

\section{Methods}

\section{Sections and sampling}

The Badenian transgression was studied in two sections in the Carpathian bend area in the Romanian Carpathian Foredeep (Campiniţa (CA) and Brebu (BR) sections) and in three sections in the northern Transylvanian Basin (Valea Dracului (DV), Ciceu-Giurgesţi (CG) and Cepari (CP) sections) (Figs. 3, 4). They are described in detail in Sant et al. (2019). Besides the flooding boundary, the Campiniţa $(155 \mathrm{~m})$ and Brebu sections $(\sim 400 \mathrm{~m})$ also cover a large pre-flooding interval.

Samples for micropaleontological and paleomagnetic analyses were taken with a resolution of $\sim 1-2 \mathrm{~m}$ from the Valea Dracului, Ciceu-Giurgesţi, Cepari and Campiniţa sections. The resolution is lower in intervals with coarsegrained material, such as sands and volcanic material. In addition, a detailed biostratigraphic sampling $(25 \mathrm{~cm}$ resolution) was carried out along the flooding boundary of the $\mathrm{CA}$ and BR sections, labeled as CX and BX. A qualitative analysis of planktonic foraminiferal assemblages was carried out on the $>125 \mu \mathrm{m}$ fraction of 88 washed residue samples focusing on biostratigraphic marker species at the Department of Chemistry, Life Sciences and Environmental Sustainability of the University of Parma. The samples containing benthic foraminifera ( $>125 \mu \mathrm{m}$ size fraction) were qualitatively examined and representative taxa were mounted on micropaleontology slides for reference. A total of 81 calcareous nannofossil smear slides were prepared and analyzed with a Zeiss Axioscope microscope under magnification $1000 \times$ at the BIOMLG Department of the University of Catania. The full description of the procedures are found in Sant et al. (2019).

A battery-powered electric drill cooled with water was used to take the total amount of 139 standard oriented paleomagnetic samples. Three tuff levels were sampled (>1 kg per sample) for ${ }^{40} \mathrm{Ar} /{ }^{39} \mathrm{Ar}$ analyses; at $6 \mathrm{~m}$ in the Cepari section, at $\sim 145 \mathrm{~m}$ in the Campiniţa section, and from the middle part of the Brebu section (marked by asterisk; Figs. 3, 4). 
a

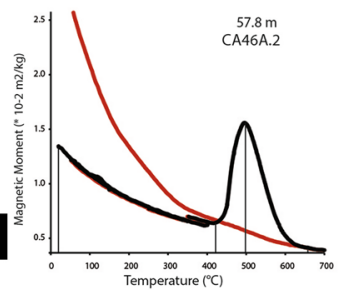

b

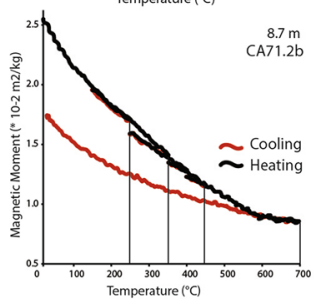

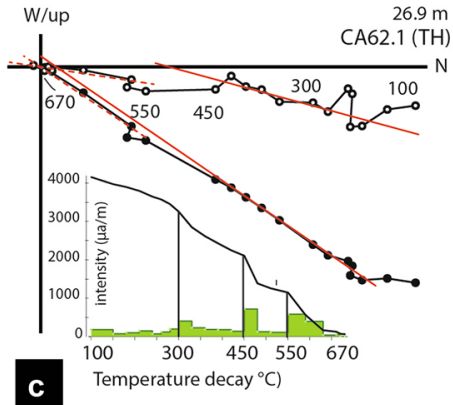

d

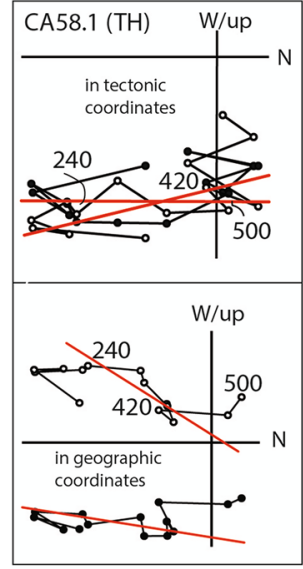

Brebu section (BR)

e Campinița section (CA)
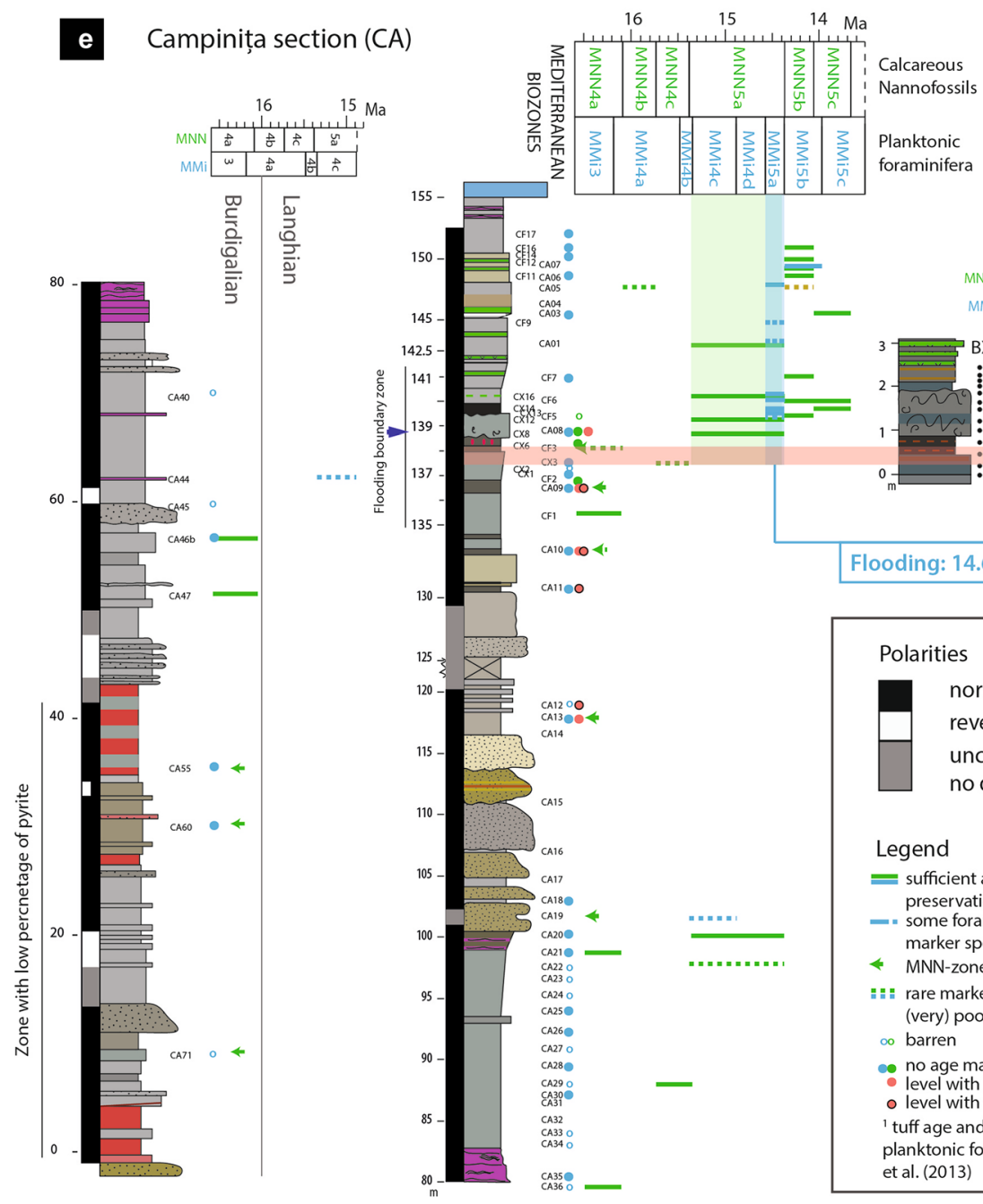

Legend

- firstrich planktonic foraminifera assemblage in this study

- base of flooding based

paleomagnetic and biostratigraphic samples

on transgressive facies

* sampled tuff levels

volcanics (general)

red-green clay/silt

gypsum(-rich)

salt breccia gray-br. clay/marl/silt

organic rich clay/marl/silt

yellow/br. sand/cong.

red-brown nodules
Polarities

normal

reversed

uncertain or

no data

Legend

= sufficient age marker species, preservation: good-moderate

- some forams evolved towards

marker species of MMi-zone above

- MNN-zone too old to fit on time scale

I: : rare marker species and/or (very) poor preservation

- barren

co no age markers

- level with benthic foraminifera

- level with tiny Streptochilus

1 tuff age and First Occurrences of

planktonic foraminifers after de Leeuw et al. (2013) 
4 Fig. 3 Overview of paleomagnetic and biostratigraphic results of the sections in the SE Carpathian Foredeep (CA, BR). Demagnetization diagrams in W/up orientation (Zijderveld 1967) (a, b) and Curie diagrams (c, d). Red (dashed) lines indicate various resolved paleomagnetic vectors. th thermal demagnetization, af alternating field demagnetization. a Irreversible behavior between 250 and $450{ }^{\circ} \mathrm{C}$ points to thermal breakdown of an iron sulphide. $\mathbf{b}$ The large peak in magnetization around $430{ }^{\circ} \mathrm{C}$ reflects pyrite-to-magnetite conversion. Sample codes and levels are displayed in the upper right corners. c Includes a decay diagram with the green blocks indicating the total decay in intensity per temperature step. d The diagram in geographic coordinates yields a feasible paleomagnetic direction, while the one in tectonic coordinates does not make sense. e Synthesis of calcareous nannofossil (green), planktonic foraminifer (blue) and magnetostratigraphic results. The shifts to open marine conditions are marked by horizontal red bars. Vertical semi-transparent green and blue boxes mark the age ranges for the flooding boundaries based on nannofossils and foraminifera, respectively. Ages in green and blue reflect the maximum ages for the onset of the open marine transgression bases on calcareous nannofossils and foraminifera, respectively. MNN and MMi biozones after Di Stefano et al. (2008), Fornaciari and Rio (1996), Iaccarino et al. (2011)

\section{Paleomagnetism and rock magnetism}

Prior to demagnetization, magnetic susceptibility per mass was measured using an Agico MFK1 Kappabridge (field strength $200 \mathrm{~A} / \mathrm{m}$; frequency $976 \mathrm{~Hz}$ ). In addition, small amounts $(\sim 30 \mathrm{mg})$ of representative samples were used for thermomagnetic experiments on a modified horizontal translation type Curie balance (noise level $5 \times 10^{-9} \mathrm{Am}^{2}$ ). All experiments were performed in paleomagnetic laboratory Fort Hoofddijk at Utrecht University. Stepwise thermal demagnetization (TH) was applied on 143 specimens (CA 83; CG 21; CP 15; DV 24) in a magnetically shielded furnace with temperature increments of $20-40{ }^{\circ} \mathrm{C}$. Further demagnetization of a sample was stopped when a clear random intensity increase was observed, indicating the built-up of a new magnetic mineral masking the original NRM. This usually occurred after $390^{\circ} \mathrm{C}$. To prevent this chemical reaction during thermal demagnetization, a dual TH-AF method was tested on a small selection of samples (20 samples). A sample was first stepwise thermally demagnetized and measured up to $350{ }^{\circ} \mathrm{C}$ and subsequently demagnetized by $\mathrm{AF}$ demagnetization.

Alternating field demagnetization (AF) was executed on 33 specimens using a laboratory-built automated measuring device applying sixteen $2-20 \mathrm{mT}$ increments up to $100 \mathrm{mT}$ by means of an AF-coil interfaced with the magnetometer (Mullender et al. 2016). After both magnetic cleaning methods (AF and $\mathrm{TH}$ ), the natural remanent magnetization (NRM) was measured on a $2 \mathrm{G}$ Enterprises DC SQUID magnetometer (noise level $3 \times 10^{-12} \mathrm{Am}^{2}$ ). The per component demagnetization scheme of Dankers and Zijderveld (1981) was used to avoid measuring a large GRM during AF demagnetization. The paleomagnetic results were analyzed in Zijderveld plots and quantified using the least square method on at least four consecutive demagnetization steps (Kirschvink 1980; Zijderveld 1967) via the open access online platform Paleomagnetism.org (Koymans et al. 2016). The paleomagnetic results are described in detail in Supplementary Material B.

\section{Radioisotopic dating}

The bulk tuff samples of Cepari (CPA), Campiniţa and the Brebu section were processed at the Mineral Separation facility of the Faculty of Earth and Life Sciences of VU University in Amsterdam. In several steps, the tuffs were crushed into blocks of $\sim 1 \mathrm{~cm}^{3}$, disintegrated in a diluted calgon solution with a Robot Coupe blixer 4 v.v. and ultrasonic bath, wet sieved and dry sieved until a fraction of $90-500 \mu \mathrm{m}$ was left. At this point, microscope analyses revealed that only sample CPA (with generally angular grains) contained high-quality biotite grains suitable for radio-isotopic dating. Biotite grains were separated using heavy liquids (diiodomethane; $\rho>3.00 \mathrm{~g} / \mathrm{cm}^{3}$ ). During the final hand-picking step, the thickest, most angular hexagonal biotite minerals of the size fraction 500-400 $\mu \mathrm{m}$ and the ones without inclusions, as visible under an optical microscope, were selected for radioisotopic dating.

Mineral separates were packed in a $6 \mathrm{~mm}$ ID AI vial together with Fish Canyon Tuff sanidine (FCs) standards. Samples and standards were irradiated at the Oregon State University TRIGA reactor in the cadmium shielded CLICIT facility for $12 \mathrm{~h}$.

${ }^{40} \mathrm{Ar} /{ }^{39} \mathrm{Ar}$ analyses were carried out at the geochronology laboratory of the VU University on an ARGUS VI+, which is a high sensitivity, low-resolution multi-collector noble gas mass spectrometer with an internal volume of $710 \mathrm{ml}$. The mass spectrometer is equipped with four Faraday cups at the $\mathrm{H} 2, \mathrm{H} 1, \mathrm{AX}$ and $\mathrm{L} 1$ positions and two compact discrete dynodes (CDDs) at positions L2 and L3. The system is equipped with a $10^{12} \mathrm{Ohm}$ amplifier on $\mathrm{H} 2$ and $10^{13} \mathrm{Ohm}$ amplifiers on $\mathrm{H} 1, \mathrm{AX}$ and $\mathrm{L} 1$ cups. The resolution of the system is $\sim 200$ and, therefore, does not resolve hydrocarbon or chlorine interferences. The ARGUS VI + has an NP10 getter and ion gauge on the source of the mass spectrometer. The NP10 getter is run cold and the ion gauge is turned off during analyses, because of its pumping capacity for argon. Samples were run on H2-L2 collectors. Sixteen single grain fusions were performed on sample CPA. Data reduction is done in ArArCalc (Koppers 2002). Ages are calculated with decay constants after Min et al. (2000) and $28.201 \pm 0.022 \mathrm{Ma}$ for FCs (Kuiper et al. 2008). The atmospheric air value of 298.56 from Lee et al. (2006) is used. All relevant procedures and analytical data for age calculations can be found online (Supplementary Data C). 
Legend

ㄴ sufficient age marker species, preservation: good-moderate

- some forams evolved towards

marker species of MMi-zone above

- MNN-zone too old to fit on time scale

In: rare marker species and/or (very) poor preservation

o barren

$\bullet$ no age markers

- level with studied benthic foraminifera

1 tuff age and First Occurrences of

planktonic foraminifers after de Leeuw

et al. (2013)

Polarities

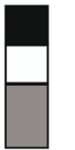

normal

reversed

uncertain or

no data
Valea

Dracului

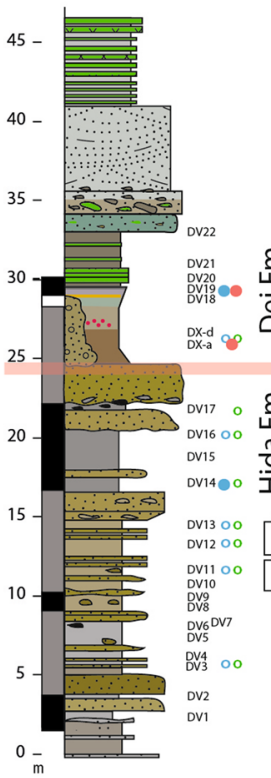

Ciceu-Giurgești
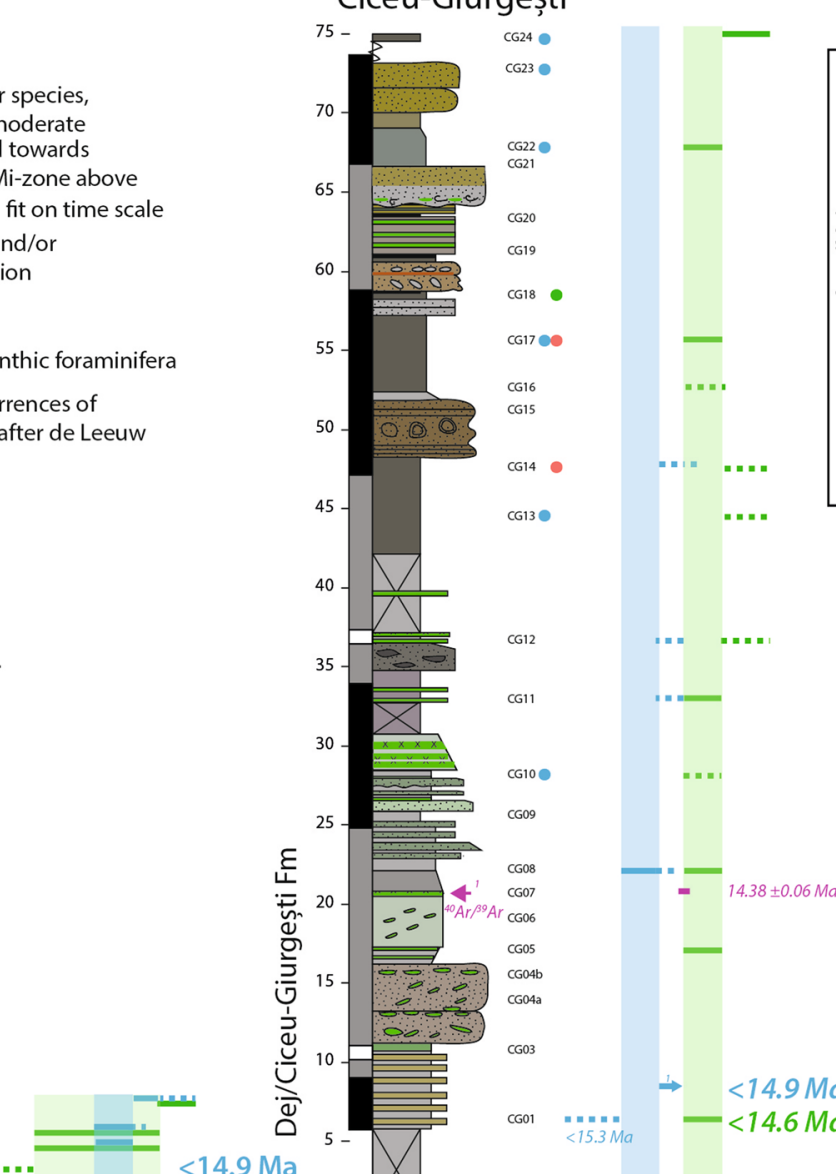
........ < < $15.3 \mathrm{Ma}$ $>15.35 \mathrm{Ma}$ 오 $_{16}$ 15
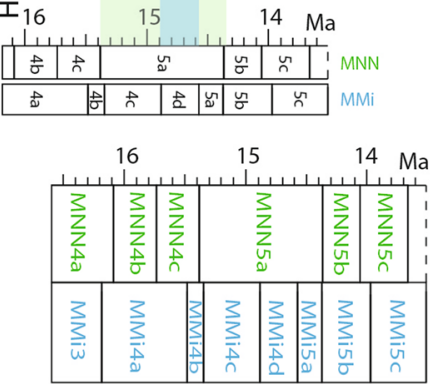

BIOZONES

Calcareous

Nannoplankton

Planktonic

foraminifers
Fig. 4 Synthesis of calcareous nannofossil (green), planktonic foraminifer (blue), magnetostratigraphic results and ${ }^{40} \mathrm{Ar} /{ }^{39} \mathrm{Ar}$ dated tuff levels (purple) of three sections in the $\mathrm{N}$ Transylvanian Basin (DV, CG, CP). MNN and MMi biozones after Di Stefano et al. (2008), Fornaciari and Rio (1996), Iaccarino et al. (2011). The ${ }^{40} \mathrm{Ar} /{ }^{39} \mathrm{Ar}$ ages in CG and DV are after de Leeuw et al. (2013). The shift to open marine conditions is marked by horizontal red bars. Vertical semitransparent green and blue boxes mark the age ranges for the flooding boundaries based on nannofossils and foraminifera, respectively.
Ages in green and blue reflect the maximum ages for the onset of the open marine transgression bases on calcareous nannofossils and foraminifera, respectively. See the legend and text for more details. ${ }^{40} \mathrm{Ar} /{ }^{39} \mathrm{Ar}$ results for all measured biotite grains of sample CPA $(6 \mathrm{~m}$, section $\mathrm{CP}$ ). The youngest reliable age is marked in blue. The red zone shows the mean age based on the four grains marked in red. The different approaches for age interpretation are described in "Integrated (chrono)stratigraphy and environments" of the main text 


\section{Results}

\section{Paleomagnetic results}

In all studied sections, AF demagnetization resulted in stable vectors at least in the range $20-32 \mathrm{mT}$, with exceptions up to 60 or $80 \mathrm{mT}$. Thermomagnetic experiments (Curie Balance) together with thermal demagnetization results show that two groups of samples exist in the sections (Fig. 3a-d).

The majority of the NRMs from all samples belong to the first group and are stable within the temperature range $180^{\circ} \mathrm{C}$ to max. $390{ }^{\circ} \mathrm{C}$. Above this temperature, pyrite converts into magnetite and the original signal is masked by a random magnetic vector visible during thermal demagnetization and in thermomagnetic experiments, complicating interpretation of the paleomagnetic signal (Fig. 3a). The combined TH-AF method could resolve the magnetic vector only in some limited cases (Supplementary Data B). The presence of pyrite $\left(\mathrm{FeS}_{2}\right)$ throughout the majority of the sections suggests that sub-oxic to anoxic bottom conditions occurred frequently in the $\mathrm{N}$ Transylvanian Basin and SE Carpathian foredeep during the studied period (Berner 1970, 1984; Rickard and Luther 2007). In contrast, the interval with mottled gray, green and red beds in the lowermost part of CA $(0-40 \mathrm{~m})$ lacks pyrite and comprises the second group of samples. Most samples carry two or three higher temperature components with the same polarity (Fig. 3b). Their magnetic components are generally stable in the temperature ranges: $180-300{ }^{\circ} \mathrm{C}$ or $180-450{ }^{\circ} \mathrm{C}$, $>300-550{ }^{\circ} \mathrm{C}$, and $>550-660{ }^{\circ} \mathrm{C}$, respectively, reflecting the magnetic carriers magnetite $\left(\max .550{ }^{\circ} \mathrm{C}\right)$ and hematite (up to $\sim 660{ }^{\circ} \mathrm{C}$ ) (Fig. 3c). In addition, the presence of an iron sulphide is suggested by irreversible behavior in the range $250-420^{\circ} \mathrm{C}$ in the thermomagnetic runs. Better oxygenated conditions and/or a higher terrestrial influx is indicated by the frequent occurrence of magnetite in the interval 100-135 $\mathrm{m}$ in the Campiniţa section.

All sections are dominated by normal polarity (Figs. 3e, 4). The long pre-flooding interval in Campiniţa contains several short reversed horizons in the basal part (18-$60 \mathrm{~m})$. DV has one reversed sample just above the flooding boundary, and CP contains one $\sim 10 \mathrm{~m}$ above the transgressive surface. However, caution is needed for the use of these data for magnetostratigraphy, because the scatter in paleomagnetic directions in all sections is high and indications for partial remagnetization exists. The mean inclination of the Campiniţa section is abnormally low $\left(\sim 3^{\circ}\right)$, which might reflect the partial overprint of reversed directions and/or a normal field overprinting an older reversed field. Sample CA58.1 has a reversed vector between 240 and $420{ }^{\circ} \mathrm{C}$ when plotted in geographic coordinates, while in tectonic coordinates a realistic magnetic direction cannot be recognized (Fig. 3d). This implies a reversed overprint. For CG and DV, the mean directions in geographic coordinates are closer to the present-day field direction than those in tectonic coordinates, suggesting that part of the NRM might be overprinted by a recent magnetic field (Supplementary Data B).

\section{Radioisotopic results}

All ${ }^{40} \mathrm{Ar} /{ }^{39} \mathrm{Ar}$ measurements with a high percentage of radiogenic ${ }^{40} \mathrm{Ar}^{*}(>85 \%)$ and a low value for ${ }^{37} \mathrm{Ar}_{\mathrm{Ca}}(<2.5 \mathrm{fA}$; and, therefore, Ca-poor minerals) are considered reliable. This is valid for thirteen out of sixteen single biotite grain measurements of tuff level CPA in the Cepari section (Fig. 4). The ages of these grains range between $14.29 \pm 0.02$ and $14.86 \pm 0.02 \mathrm{Ma}$. Due to the volcanoclastic nature of the tuff, reworked, detrital grains might be present in the sample. These components are older than the eruption age, so the oldest grains likely do not represent the eruption age. Following this reasoning, we could state that the youngest reliable grain with an age of $14.29 \pm 0.02 \mathrm{Ma}$ is the best measure of the eruption age. Alternatively, we could assume that some ${ }^{40} \mathrm{Ar}$ loss occurred and that the eruption age is approximated best by a statistically sound mean value (data points are included until MSWD $>T$ test statistic using a $2 \sigma$ confidence limit). This approach is similar to that of $\mathrm{U} /$ $\mathrm{Pb}$ studies where the youngest grain(s) might represent $\mathrm{Pb}$ loss and the oldest grain(s) xenocrystic components (e.g., Sahy et al. 2015). In this case level, CPA has an age of $14.35 \pm 0.04 \mathrm{Ma}$. If we simply consider the full age range of all grains, the tuff is younger than $\sim 14.6 \mathrm{Ma}$.

${ }^{40} \mathrm{Ar} /{ }^{39} \mathrm{Ar}$-dating on biotite is regularly reported to be less precise than dating on $\mathrm{K}$-feldspar, because the presence of some extraneous ${ }^{40} \mathrm{Ar}$ in biotite grains will result in overestimated age values (e.g., Hora et al. 2010). Another phenomenon which can lead to an overestimated age of platy minerals such as biotite is loss of ${ }^{39} \mathrm{Ar}$ during recoil (Onstott et al. 1995; Turner and Cadogan 1974). However, for our study this effect is expected to be very small since the net loss of ${ }^{39} \mathrm{Ar}$ is assumed to be trivially small for relatively large grains (e.g., Hall 2014). Our measured age range in the Cepari tuff sample is overlapping with the ${ }^{40} \mathrm{Ar} /{ }^{39} \mathrm{Ar}$ ages for the base of the Dej tuff in different sections in the NW Transylvanian Basin as presented by de Leeuw et al. (2013), being $14.37 \pm 0.06$ and $14.36 \pm 0.06 \mathrm{Ma}$ and based on K-feldspars. This suggest that extraneous ${ }^{40} \mathrm{Ar}$ and recoil only affected the age determinations of our biotite sample to a small extent. An overview of the analytical data and procedures is found in Supplementary Material C. 


\section{Integrated (chrono)stratigraphy and environments}

\section{Flooding boundary characteristics}

The flooding boundary in the SE Carpathian Foredeep is in both sections (CA, BR) marked by a thin $(<0.5 \mathrm{~m})$ anoxic (potentially sapropelic) interval characterized by black clays with jarosite and secondary iron oxide crusts that probably are the result of the pyrite oxidation (Fig. 3e). It is followed by silt/fine sands with water escape structures and marls with tuffs. Benthic foraminifera below the anoxic interval indicates some oxygen restriction, whereas the ones just above suggest a shift to a more oxic, shallow marine environment with deviating salinity (Sant et al. 2019).

In addition, tiny $(<125 \mu \mathrm{m})$ Streptochilus/Bolivina foraminifera were found in a few samples in the 20 m-interval below the main flooding boundary in Campiniţa (CA12, CA11, CA10 and CA9B, 118-134 m). Similar foraminifera are known from the pre-flooding strata of the $\mathrm{N}$ Transylvanian Basin (Beldean et al. 2010, 2013), but it is the first time that these tiny foraminifera are documented from a similar stratigraphic position in the Romanian Carpathian Foredeep. Streptochilus/Bolivina foraminifera have a tychopelagic lifestyle, meaning that they can be both benthic and planktonic (Darling et al. 2009; Smart and Thomas 2007). This attribute makes them very adaptable to new circumstances and suitable to invade a new environment, such as one with highly fluctuating nutrient conditions (Beldean et al. 2010). They are also commonly associated with oxygen minimum zones (Bernhard and Sen Gupta 1999; Nigam et al. 2007; Smart and Thomas 2007).

Apart from the appearance of a rich Langhian foraminiferal assemblage, the flooding boundaries in the Transylvanian sections do not have much in common. At Valea Dracului, the flooding base comprises brown, green-gray and purple-gray clays followed by marl with tuffs. A distinct level $(1 \mathrm{~cm})$ with rounded grains with iron oxides occurs within the clays. Rare and recrystallized foraminifera suggest shallow-marine waters. In the Cepari section, the flooding boundary is characterized by gray clays cut by a poorly sorted sand with sand intraclasts. Abundant large Miocene benthic foraminifera and ostracods indicative for a shallow shelf with a high organic load are present below the boundary.

\section{Timing of the flooding in the SE Carpathian Foredeep}

Only samples with moderate-good biostratigraphic preservation are taken into account for the chronostratigraphy (Sant et al. 2019). The pre-flooding (Doftana Fm) sediments have a generally poorly preserved fossil content with few age markers. Nevertheless, the biostratigraphic data suggest that the uppermost part of the Doftana Fm is Langhian in age, which is in agreement with (Orbocea et al. 1986b), and that marine incursion occurred before 14.6 Ma (Fig. 3e). The interval between 98 and $102 \mathrm{~m}$ contains marker fossils attributed to the Langhian Biozone MNN5a and most likely MMi4c (P. glomerosa glomerosa), indicating a period with a marine incursion (Sant et al. 2019). Following the MNN4a attribution of sample CA36, the base of the Langhian stage is positioned above the gypsum interval around level $80 \mathrm{~m}$, while an even lower position $\sim 60 \mathrm{~m}$ cannot be excluded because of the uncertain MMi4c attribution of sample CA44. The dominantly normal polarity for the Langhian part of the section (60/80-153 m) indicates that the majority of the paleomagnetic signal is overprinted because it does not correspond to the Global Polarity Time Scale (Hilgen et al. 2012). The normal polarity with some reversed intervals (interval 0-58 m) might correspond to the late Burdigalian Chron C5Cn.

The biostratigraphic age data of the transgressive sequences in Campiniţa and Brebu in the SE Carpathian Foredeep are in good agreement with each other (Fig. 3e). In both sections, the nannofossil and foraminifera data at the flooding boundary overlap, and show a distinct shift in age (and preservation) compared to the samples below the boundary. The flooding correlates to the MNN5a (15.3-14.4 Ma) and MMi5a (14.6-14.4 Ma) biozones, indicating that the open marine conditions in this isolated part of the Carpathian Foredeep region installed most probably after 14.6 Ma.

\section{Timing of the flooding in the N Transylvanian Basin}

All analyzed samples from the pre-flooding strata (Hida Fm) were barren in planktonic foraminifera and calcareous nannofossils. In Valea Dracului, the MNN5a zone overlaps with the MMi4d zone, narrowing the onset of open marine conditions down to 14.9-14.6 Ma (Fig. 4). One good quality reversed polarity sample just below the Dej tuff and appearance of $O$. suturalis could potentially be correlated to Chron C5ADr ( 14.78-14.61 Ma) (Hilgen et al. 2012).

The biostratigraphic data at the base of the CiceuGiurgesți section are scarce and the interpreted biozones are conflicting, with planktonic foraminifera indicating older ages (14.9-14.4 Ma) than the nannofossils (<14.4 Ma). The older age determination based on planktonic foraminifera could be due to the uncertain classification of the Praeorbulina/Orbulina group because of the poor preservation of the fossils (Sant et al. 2019). De Leeuw et al. (2013) described the finding of $P$. glomerosa (sensu Blow) at $\sim 5 \mathrm{~m}$ below the base of our section, and the FO of $O$. suturalis at $\sim 8 \mathrm{~m}$ stratigraphic height. This suggests (using the Mediterranean biochronology) an age range of 15.3-14.6 Ma for the basal part $(<8 \mathrm{~m})$. Their ${ }^{40} \mathrm{Ar} /{ }^{39} \mathrm{Ar}$ age around $20 \mathrm{~m}$ is in agreement with the nannofossil data from this study 
(MNN5b) and their study (de Leeuw et al. 2013). Like in the Valea Dracului section, a reversed sample is present just below the appearance of Dej tuff elements, which could match with Chron C5ADr.

In Cepari, the age range of the CPA tuff (14.6-14.3 Ma) is overlapping with the calcareous nannofossil MNN5a Subzone, while the scarce foraminifera samples might suggest a slightly older age (Fig. 4). Note that the poor preservation of Praeorbulina glomerosa and perhaps Orbulina suturalis could hamper the recognition of Orbulina suturalis in sample C7B. No age markers were encountered in the basal part below the transgression.

Summarizing, the widespread open marine Badenian Sea in the $\mathrm{N}$ Transylvanian Basin most probably installed in the period 14.9-14.4 Ma (MMi4d), relying mostly on data from the DV and CP sections. Scarce or poorly preserved planktonic foraminifera in the clastic base of the transgressive sequences in the CG and DV sections hint at the presence of the MMi4c Biozone (15.3-14.9 Ma), showing that episodic influxes of water with Mediterranean foraminifera in the study areas occurred the earliest by $15.3 \mathrm{Ma}$, but that a deeper and fully marine environment throughout the basin was most probably installed later. Our proposed age range for the transgression fits much better with the most recent radio-isotopic ages between 14.6 and 14.2 Ma for the overlying Dej tuffs than the ages provided by previous studies based on open ocean (Atlantic) biochronologies ( 16.4 Ma) (Beldean et al. 2013; de Leeuw et al. 2013; Krézsek and Filipescu 2005).

No consensus exists about the salinity in the N Transylvanian Basin. Although older studies inferred a fluviodeltaic setting for the majority of the Hida Fm (Popescu 1975), more recent biostratigraphic and sedimentological studies propose almost normal levels of salinity for most
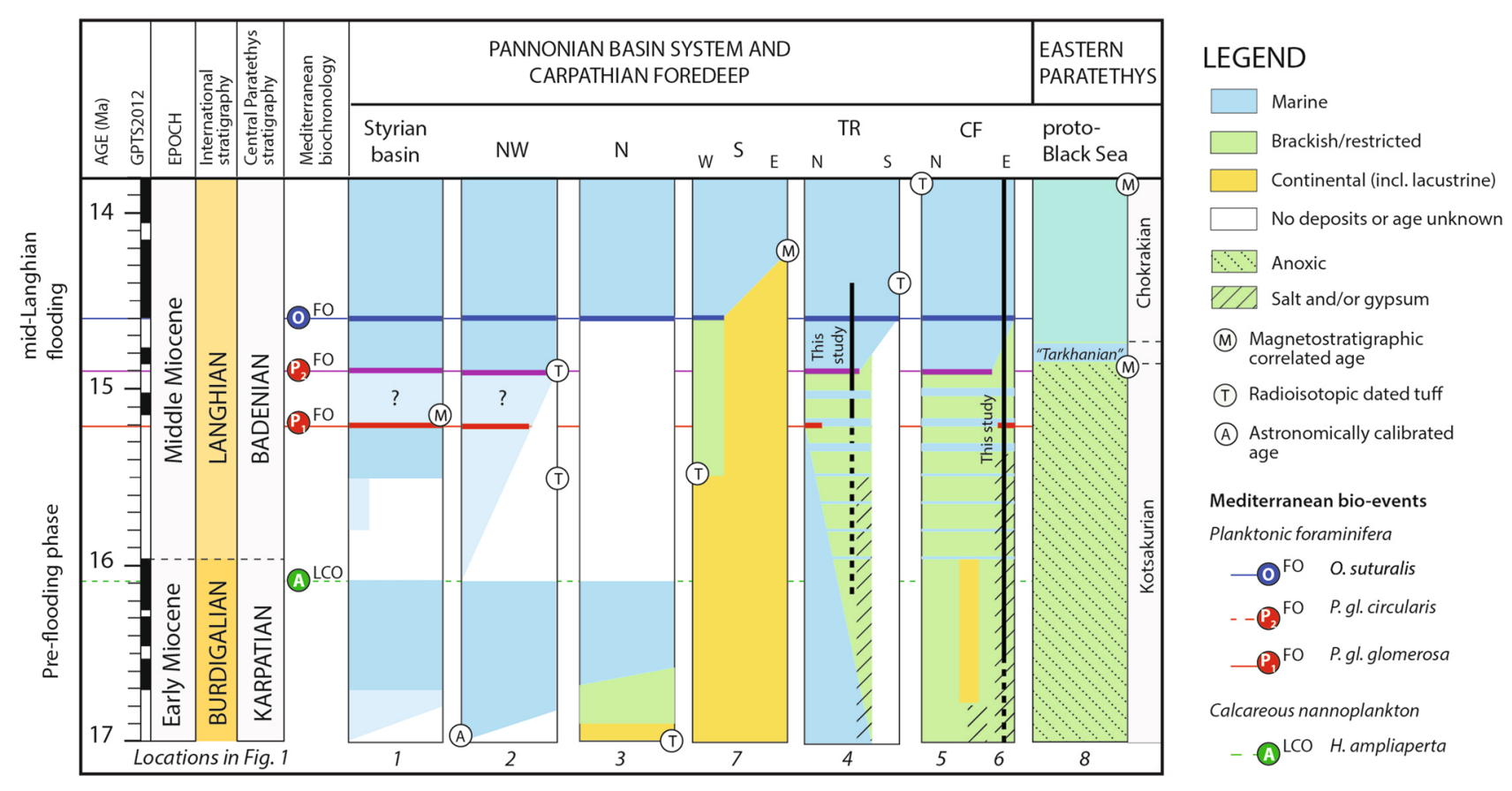

Fig. 5 Compilation of paleoenvironmental and age data for key areas in Central Europe. Biochronology follows the Mediterranean. Timescale (GPTS) after Hilgen et al. (2012). Note that the FO of Praeorbulina in the Central Paratethys refers to the FO of $P$. gl. glomerosa, occurring always together with $P$. gl. curva (Rögl et al. 2002b). The Slovenian strait to the Mediterranean was most likely open since $\sim 17 \mathrm{Ma}$ because the onset of the late Burdigalian sea is astronomically correlated to be $\sim 17 \mathrm{Ma}$ in the NW Pannonian region (Korneuburg Basin; Zuschin et al. 2014). The main literature used for the compilation of the basins: Styrian Basin (Kollmann 1965; Auer 1996; Rögl et al. 2002b; Hohenegger et al. 2009; Spezzaferri et al. 2009); NW-Austrian Molasse (Rögl et al. 2003; Ćorić and Rögl 2004; Ćorić et al. 2004) and Vienna basin-(Andreyeva-Grigorovich et al.
2001; Rögl et al. 2002a; Kováč et al. 2004; Harzhauser et al. 2018); N-Nograd/South Slovakian-(Vass 2002b; Pálfy et al. 2007; Nagymarosy and Hámor 2012; Selmeczi et al. 2012; Püspöki et al. 2017); S-North Croatian basins (Baldi 2006; Ćorić et al. 2009; Mandic et al. 2012; Kovačić et al. 2016; Pavelić and Kovačić 2018), northern Bosnia (Mandic et al., 2019b; Pezelj et al., 2013) and Dinaride Lake System (de Leeuw et al. 2012); TR-Transylvanian Basin (see caption Fig. 2); CF-Polish-Ukrainian (Andreyeva-Grigorovič et al. 1997; Oszczypko and Oszczypko-Clowes 2011; Oszczypko et al. 2014, 2016) and Romanian Carpathian Foredeep (see caption Fig. 2); proto-Black Sea (Gontsharova 1991; Palcu et al. 2017, 2019). See Sant et al. (2017) and Sant (2018) for more background information 
of the pre-flooding succession in the NW Transylvanian basin (Beldean et al. 2010, 2012, 2013; Székely and Filipescu 2016). In the period right before the Badenian flooding, the sea became shallow and restricted because of the prograding delta front, which is especially noted in the NE Transylvanian Basin (Beldean et al. 2013).

\section{The mid-Langhian marine flooding in the Paratethys}

\section{Temporal and spatial extent}

The timing of the installment of the Badenian Sea in the study areas in the N Transylvanian Basin $(<14.9-14.4 \mathrm{Ma})$ fits very well with the timing in the neighboring PolishUkrainian Foredeep (4-5 in Fig. 5). Like in the Transylvanian Basin, several marine ingressions marked by scarce Mediterranean fossils are known from the late Burdigalian onwards, but most biostratigraphic data with P. glomerosa circularis and/or $O$. suturalis point to a definite transgression of the sea after 14.9 Ma (Andreyeva-Grigorovič et al. 1997; Andreyeva-Grigorovich et al. 2008; Oszczypko et al. 2006, 2016; Oszczypko and Oszczypko-Clowes 2011).

The environmental evolution of the restricted Carpathian Bend area of the East Carpathian foredeep (i.e. Campiniţa section) followed a similar pattern with several marine incursions before the mid-Langhian, and the installment of the permanently open marine Badenian sea after 14.6 Ma (O. suturalis) (Fig. 5). The same is valid for most marginal/shallow marine areas, including the NE Vienna basin (2 in Fig. 5) (Harzhauser et al. 2018), SE Transylvanian Basin (Ilie 1951) and South Carpathian Foredeep (Iorgulescu 1951). The basal flooding strata in the North Pannonian Basin (Hámor 1985; Kováč et al. 2007; Selmeczi et al. 2012; Vass 2002a) and North Croatian basins (Ćorić et al. 2009) (3 and 7 in Fig. 5) are uniformly associated with $O$. suturalis $(<14.6 \mathrm{Ma})$. The transgression reached the S Pannonian Basin relatively late, namely between 14.6 and 14.2 Ma (Ćorić et al. 2009; Mandic et al. 2019a, b; Pezelj et al. 2013).

The timing and mode of the onset of the marine flooding in the western areas (1-2 in Fig. 5) is not completely resolved. In the Styrian Basin (1 in Fig. 5) and Upper Austrian Molasse basin, a basal flooding with scarce $P . g l$. glomerosa, $P$. glomerosa curva and/or $H$. waltrans was reported, implying a maximum age of $15.5 \mathrm{Ma}$ (Ćorić and Rögl 2004; Hohenegger et al. 2009; Rögl et al. 2002b; Spezzaferri et al. 2009). However, it is uncertain whether these basal sediments reflect the onset of the long-lasting early Badenian Sea or only reflect a short marine phase.

Summarizing, the widespread "mid-Langhian" flooding in the Central Paratethys occurred in most regions after $\sim 15$ Ma. This coincides with the "Tarkhanian" marine phase in the Eastern Paratethys (Euxinian Basin) that was magnetostratigraphically dated at $14.85 \mathrm{Ma}$ (Palcu et al. 2019). This phase was caused by marine influx from the East Carpathian Foredeep (Central Paratethys) to the proto-Black Sea basin (Eastern Paratethys) via the Carasu strait (Chiriac 1969) (Figs. 5, 6).

Outflow of nutrient-rich brackish water from Eastern Paratethys (similar to present day Black Sea outflow and temporary nannoplankton blooms in the Marmara Sea) may be related to the temporarily blooms of the opportunistic Streptochilus foraminifera just below the flooding boundary in the studied areas of the East Carpathian Foredeep and Transylvanian Basin (Beldean et al. 2010, 2013). The temporary low oxic setting and anoxic levels in the Campiniţa and Brebu sections might be related to the low-density brackish outflow plume of Black Sea water (Liu et al. 2017; Palcu et al. 2019). The suggestion by Beldean et al. (2010) that the Streptochilus blooms might have a similar age range as the blooms in the Atlantic and Indian Oceans ( 19-17 Ma) is erroneous. The tiny Streptochilus in the SE Carpathian Foredeep are assigned to the Langhian stage $(<16 \mathrm{Ma})$, and in the Transylvanian Basin (DV section) they occur up to $\sim 5 \mathrm{~m}$ below the first level with Langhian fossils (Beldean et al. 2013) (Fig. 4). The Streptochilus blooms could serve as ecological markers for the initial phase (or phases) of the marine transgression in the eastern part of the Central Paratethys.

Our new ages can be used to improve paleogeographic reconstructions (Fig. 6a). Around $\sim 14.2$ Ma the Badenian Sea had spread out to the majority of the basins in Central Europe. It significantly expanded north-eastward in the Polish-Ukrainian Foredeep (at least $70 \mathrm{~km}$ ), and branched out towards the Republic of Moldova (Goncharova and Il'ina 1997; Oszczypko and Oszczypko-Clowes 2011). The S Transylvanian Basin was most-probably well-connected with the S and SE Carpathian Foredeep (Iorgulescu 1951), and also to the southern Pannonian Basin via a corridor south of the Apuseni Mountains (Pop 1951; Roşca 1951). The connection between the NW-SE oriented Focsani depression in the East Carpathian Foredeep and the SW Transylvanian Basin most likely persisted in the Langhian (Mirăuţa 1967; Tărăpoancă 2003). See Supplementary Material D for background information on the facies map in Fig. 6a.

\section{Drivers for the mid-Langhian flooding}

The mid-Langhian flooding took place in a dynamic period with large scale tectonic events and global sea-level fluctuations and is probably the result of a complex interplay between those processes (Balázs et al. 2016; John et al. 2011; Kovác et al. 2017b, 2018; Zachos et al. 2001). The geodynamic processes (i.e. active rifting and uplift) controlled to 

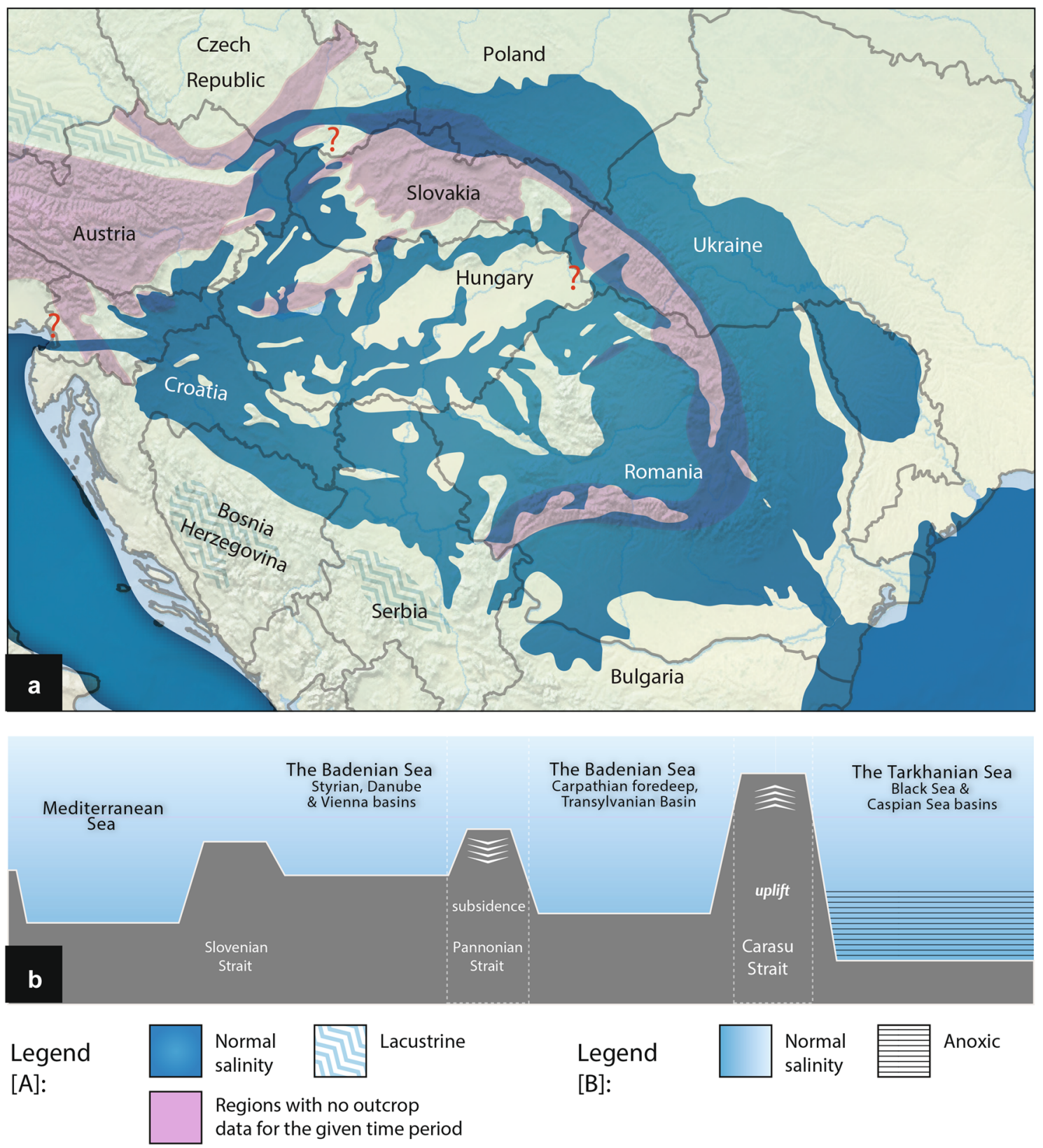

Fig. 6 a Map showing the (minimal) outline of the open marine Badenian Sea ( $14 \mathrm{Ma})$ based on present-day outcrops supplemented by stratigraphic data from boreholes and seismic profiles, which were mostly used in areas with a large post-Middle Miocene cover and/or Miocene sediments in folded nappes (e.g., Carpathian fold and thrust belt). Some paleoconnections are inferred based on structural data

a large extent the accommodation space, sedimentation rates and opening or closure of connections between the different basins (Báldi et al. 2002; Horvath et al. 2006; Matenco and Radivojević 2012; Palcu et al. 2017). As a result, the expression of the flooding is slightly different in each area. For example, the Ugljevik region in the SE Pannonian basin was flooded after 14.2 Ma (Mandic et al. 2019b; Pezelj about the timing of uplifted terranes. Question marks denote uncertain areas, usually as a result of a lack of age data. Note: these are no palinspastic reconstructions; see Kováč et al. (2017a, b) for palinspastic maps. Background information with references for each area are depicted in Supplementary Material D. b Simplified gateway configuration for the Badenian Sea

et al. 2013), which suggests that in this marginal area the space and/or connection to the sea was mainly controlled by tectonics.

A combined record of eustatics in the west Atlantic and Pacific oceans suggests a sea-level rise of $\sim 30 \mathrm{~m}$ around 14.7 Ma (right after the sea-level drop associated with Mi3a isotope event), followed by a slow rise until $\sim 14.2 \mathrm{Ma}$ (John 
et al. 2011; Kominz et al. 2008). This eustatic phase overlaps largely with the timing of the expansion of the normal saline Badenian Sea which we here constrained to the age range 14.9-14.4 Ma. Thus, it is possible that the mid-Langhian flooding was triggered by this global sea-level rise. The rise is in agreement with the fact that the fully marine water transgressed far over the platforms next to the foredeeps, rapidly transformed lakes into marine basins (Kovačić et al. 2016; Krézsek and Bally 2006; Pavelić and Kovačić 2018) and spilled over into the Eastern Paratethys via the Carasu strait (Goncharova and Il'ina 1997; Holcová et al. 2018; Palcu et al. 2019) (Fig. 6b).

The eustatic sea-level rise might have overcome a barrier in the region of the Trans-Hungarian Shear Zone that separated the restricted environments in the east from the (semi-restricted) marine environments in the west (Fig. 6b), allowing fully anti-estuarine circulation and oxidation of all marine areas in the Central Paratethys (Kováč et al. 2017a). Tectonic subsidence or rotations might have assisted in removing the barrier, but since the shift from pre-flooding to fully marine Badenian conditions is very sharp in most records it seemed to occur relatively fast and it is most likely that the sea level rise was the main trigger for the onset. The early Badenian sea was sustained in most places at least up to 13.8 Ma suggesting that by that time the connection to the Mediterranean had widened or deepened to retain the marine environments even after the global sea level dropped again.

\section{The pre-flooding phase}

With the "pre-flooding phase" we refer to the period of variable lacustrine, brackish and marine conditions in Central Europe between the opening of the Slovenian strait and the mid-Langhian flooding ( 17-15 Ma) (Fig. 5). Kováč et al. (2018) defined most of this period as a relative sea-level lowstand ( 16.5-15.5 Ma). The paleoenvironmental evolution of this phase is poorly understood compared to that of the widespread Badenian Sea but it deserves some attention.

It is important to stress that in many Paratethys basins all pre-flooding sediments are commonly attributed to the upper Burdigalian, based on the assumption that the base of the marine Badenian succession has the same age as the Langhian Stage of the Mediterranean ( 16 Ma). However, the much younger age for the marine flooding in many locations implies that a large part of the pre-flooding strata could actually be early Langhian in age. This is in agreement with the data from the Campinița section in the Romanian Carpathian Foredeep (this study) and stratigraphic data from other studies (Andreyeva-Grigorovich et al. 2001; Kovačić et al. 2016).

A gradual or abrupt 'brackification' towards the east during the pre-flooding phase is indicated by a general decrease in the amount of marine nannofossils and microfossils, with the richest assemblages nearby the Slovenian strait (Bartol 2009; Hohenegger et al. 2009) and poorest in the East Carpathian Foredeep (Fig. 7; Suppl. D). A snapshot during the pre-flooding phase (at $\sim 16.5 \mathrm{Ma}$ ) is depicted in Fig. 7 to exemplify a scenario with a decrease in salinity from the Slovenian strait towards the east. In this period, the north Pannonian basin was marine (Pálfy et al. 2007), while the majority of the East Carpathian Foredeep was most probably semi-restricted marine (e.g., Mirauta 1967; Rusu et al. 1996; Oszczypko et al. 2016). Connections between the Carpathian Foredeep, N Transylvanian Basin and NE Pannonian Basin most probably still existed over the rising East Carpathians (Mirăuţa 1967). The North Carpathian Foredeep was likely still isolated from the Vienna Basin and NW Carpathian Foredeep (SW Czech Republic) by the uplift of the Cieszyn-Slavkov Paleo Ridge (SE Czech Republic-SW Poland) (Oszczypko 1997; Oszczypko and OszczypkoClowes 2011). In the presented example, one large jump from marine to hyposaline conditions occurs at the location of one dominant gateway in the Pannonian Basin, potentially at the Mid-Hungarian Shear Zone (Fig. 7b). The boundary between the areas with normal and low salinities would require the presence of a paleo-strait limiting water exchange between both regions.

In some areas in the SE Carpathian Foredeep, calcareous material is completely absent (Andreyeva-Grigorovič et al. 1997). If marine calcareous fossils occur, they are confined to narrow horizons representing short marine influxes, such as in the middle part of the Campiniţa section and in other parts of the East Carpathian Foredeep (e.g., Mirauta 1967; Andreyeva-Grigorovich et al. 2008), where they are known to occur during late Burdigalian-early Langhian times. It suggests that the environments were hostile to life or poorly suited for the preservation of shells. It also implies that a fragile connection existed between the East Carpathian Foredeep and the rest of the Central Paratethys Sea (Paucă 1976).

No direct sedimentary or biostratigraphic proof exists for a sea strait between the Central Paratethys and the Eastern Paratethys (proto-Black Sea Basin) during the pre-flooding phase (Chiriac 1969; Goncharova and Il'ina 1997; Gontsharova 1991). However, new modeling data suggest that the Eastern Paratethys had a positive water budget during the pre-flooding period of the Central Paratethys (Simon et al. 2018). Moreover, tectonic data indicate that the NW-SE striking normal fault system cross-cutting the Romanian East Carpathian Foredeep and Carasu strait area could have already existed since the late Burdigalian (Tărăpoancă 2003). Therefore, it is possible that some spillover from the brackish and anoxic proto-Black Sea (Maikop Series) to the neighboring East Carpathian Foredeep occurred (Palcu et al. 2019). At that time, the Black Sea was notorious for its severe anoxic paleoenvironments with 


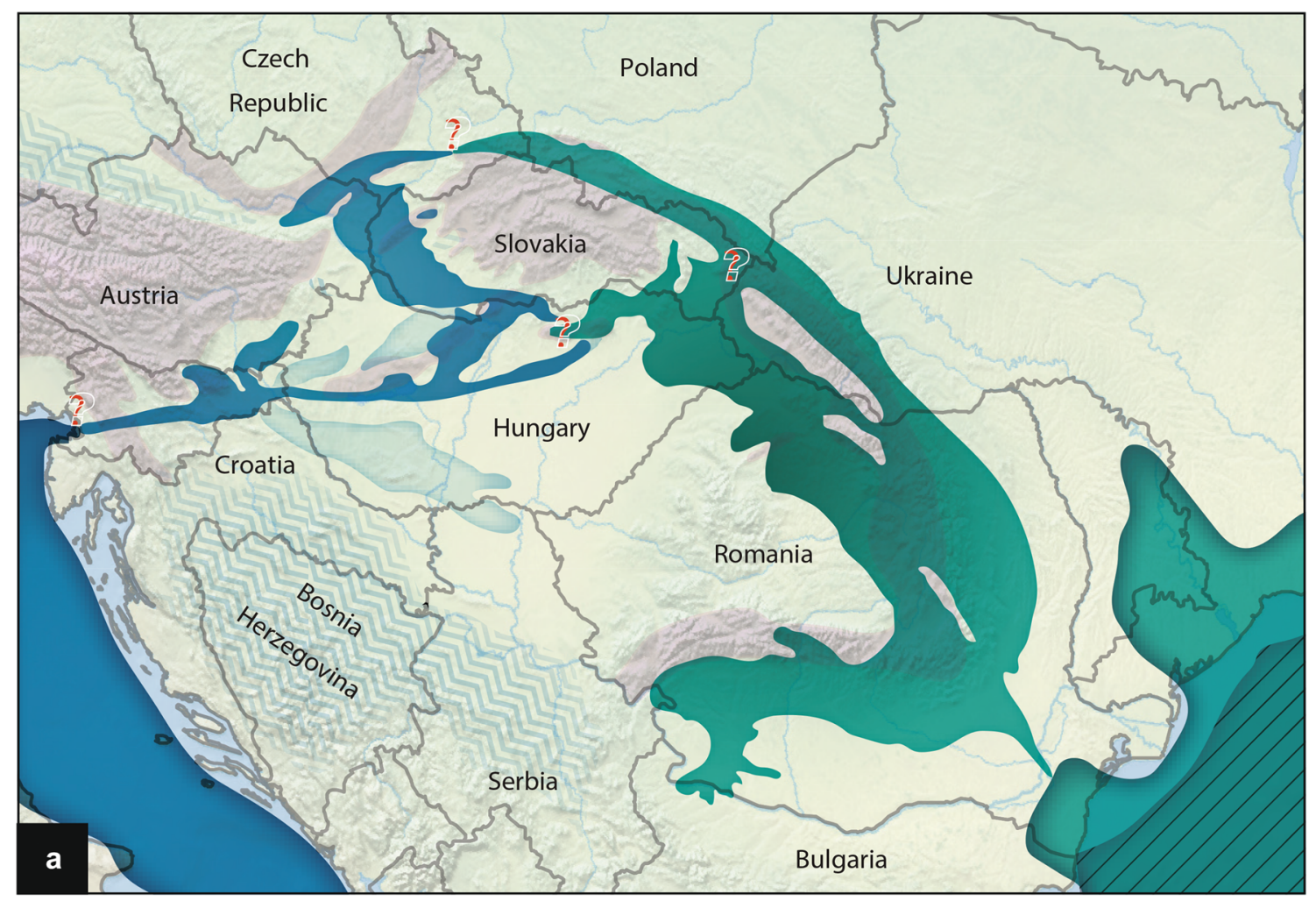

Mediterranean Sea

Central Paratethys

Eastern Paratethys
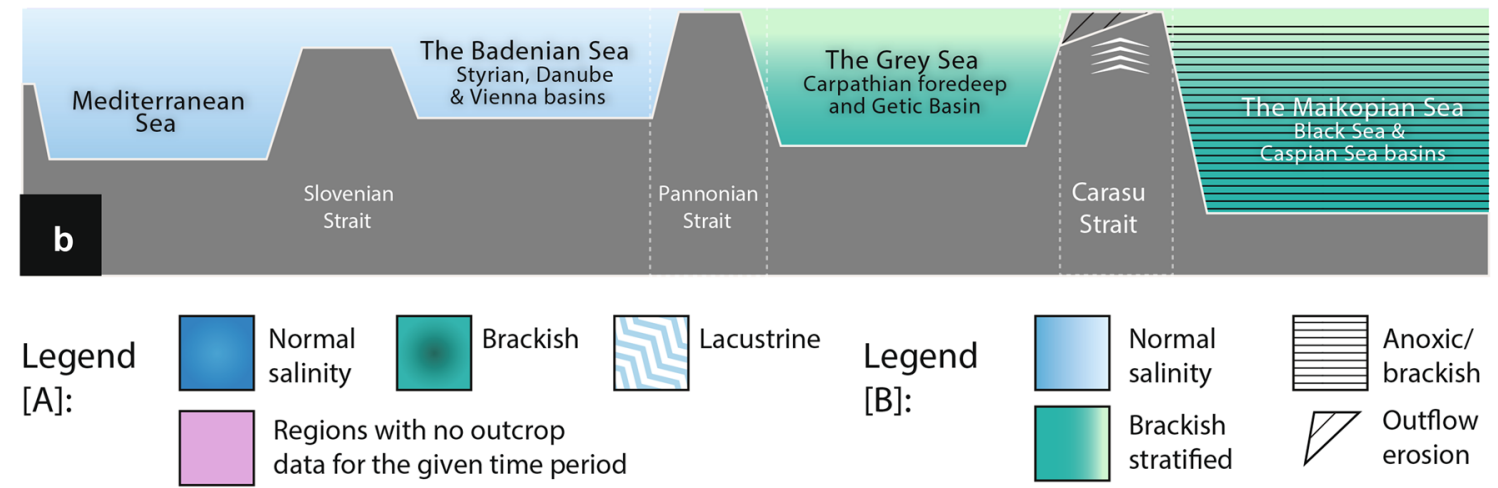

Fig. 7 a Map showing a paleogeographic scenario with the outline of the marine, brackish and freshwater basins for one snapshot during the pre-flooding phase ( $16.5 \mathrm{Ma})$. The semi-transparent marine bays in present-day Hungary are uncertain. See caption of Fig. 6 and

salinity stratification and lack of vertical circulation (Hudson et al. 2008; Katz et al. 2000; Sachsenhofer et al. 2017), so a spillover would be one way to explain the hostile environments in the foredeep. In this case, a freshwater plume would have existed in the SE Carpathian Foredeep that faded out towards the areas more distant of the Carasu strait. Another way to explain this would be a very large input of freshwater from the mountains and surrounding plains creating an antiestuarine circulation with bottom anoxia (Kováč et al. 2018).
Supplementary Material D for background information. b Simplified gateway configuration for this scenario of the pre-flooding phase. All background information on the map is found in Supplementary Material D

\section{Conclusions}

Our integrated magneto-biostratigraphic and ${ }^{40} \mathrm{Ar} /{ }^{39} \mathrm{Ar}$ data from the Transylvanian Basin and East Carpathian Foredeep provide new insights into the age and paleoenvironments of the pre-flooding and mid-Langhian marine flooding phases in Central Europe.

By applying the most recent Mediterranean biochronology, we show that marine incursions into the dominantly 
brackish basins of Central Europe (traced by horizons with preserved marine micro and/or nannofossils) occurred at least since the latest Burdigalian. Such short marine influxes have been reported throughout the Ukrainian-Romanian Foredeep areas in the late Burdigalian-early Langhian period (pre-flooding period). A progressive eastward restriction in the marine incursions in the Central Paratethys realm during the pre-flooding phase $(\sim 17-15 \mathrm{Ma})$ seems to go hand-in-hand with a decline in the presence of marine Mediterranean micro- and nannofossils. The apparently lower salinity in the eastern part of the Central Paratethys might have been enhanced by the presence of one or several sills blocking the inflow of marine water into these areas. We speculate that the striking scarcity of calcareous material of all sorts in the East Carpathian Foredeep might have been enhanced by pulses of nutrient-rich brackish water from the neighboring Eastern Paratethys via the Carasu strait region.

The widespread open marine settings of the Badenian Sea in the NW Transylvanian Basin were installed between 14.9 Ma (MMi4d biozone) and 14.4 Ma. In the marginal study area in the SE Carpathian Foredeep, fully marine conditions set in slightly later than in the NW Transylvanian Basin (14.6-14.4 Ma versus 14.9 Ma).

In the majority of the formerly brackish and freshwater basins in the north, central and southern Central Paratethys, open marine conditions were also introduced between $\sim 14.9$ and 14.4 Ma. The significant expansion of the Central Paratethys sea suggests that, besides the geodynamically controlled subsidence in the Pannonian Basin, global sea-level rise might have enhanced the change in paleogeography and paleoenvironments. This is in good agreement with the incursion of Central Paratethys open marine water into the restricted Eastern Paratethys at 14.85 Ma (regional Tarkhanian Stage).

Acknowledgements We would like to thank Jan Spierings and Zelda Zeegers for their help with the fieldwork and magnetostratigraphic measurements, Roel van Elsas for his support in the Mineral Separation Lab at the VU University, and Giovanna Gianelli for preparing samples for foraminiferal analysis in the Micropaleontology Lab of Parma University. We are also very grateful that Rocco Gennari shared information about tiny Streptochilus foraminifera with us, and that Marius Stoica helped identifying some ostracods. Finally, Michal Kováč and Samuel Rybar are thanked for fruitful discussions about the paleogeographic maps. This project was financially supported by the Dutch Organization for Scientific Research (NWO) by VICI Grant 865.10.011 of WK, and NWO Grant 864.12 of KK.

Open Access This article is distributed under the terms of the Creative Commons Attribution 4.0 International License (http://creativeco mmons.org/licenses/by/4.0/), which permits unrestricted use, distribution, and reproduction in any medium, provided you give appropriate credit to the original author(s) and the source, provide a link to the Creative Commons license, and indicate if changes were made.

\section{References}

Abdul Aziz H, Di Stefano A, Foresi LM, Hilgen FJ, Iaccarino SM, Kuiper K, Lirer F, Salvatorini G, Turco E (2008) Integrated stratigraphy and ${ }^{40} \mathrm{Ar} /{ }^{39} \mathrm{Ar}$ chronology of early Middle Miocene sediments from DSDP Leg 42A, Site 372 (western Mediterranean). Palaeogeogr Palaeoclimatol Palaeoecol 257:123-138. https://doi. org/10.1016/j.palaeo.2007.09.013

Andreyeva-Grigorovič AS, Kulchytsky YO, Gruzman AD, Lozynyak PY, Petrashkevi MI, Portnyagina LO, Ivanina AV, Smirnov SE, Trofimovich NA, Savitskaya NA, Shvareva NJ (1997) Regional stratigraphic scheme Of Neogene formations of the Central Paratethys in the Ukraine. Geol Carpathica 48:123-136

Andreyeva-Grigorovich AS, Kováč M, Halásová E, Hudáčková N (2001) Litho and biostratigraphy of the Lower and Middle Miocene sediments of the Vienna basin (NE part) on the basis of calcareous nannoplankton and foraminifers. Scr Fac Sci Nat Univ Masaryk Brun 30:27-40

Andreyeva-Grigorovich AS, Oszczypko N, Ślączka A, Oszczypkoclowes M, Savitskaya NA, Trofimovicz N (2008) New data on the stratigraphy of the folded Miocene Zone at the front of the Ukrainian Outer Carpathians. Acta Geol Pol 58:325-353

Auer J (1996) Biostratigraphische und Magnetostratigraphische Untersuchungen im Grenzbereich Unter- und Mittelmiozan (Karpatium/Badenium) Der Paratethys, Ziegelei Aflenz/Wagna, Steirisches Becken, Steiermark, Osterreich, PhD Thesis. Vienna University

Backman J, Raffi I (1997) Calibration of Miocene nannofossil events to orbitally tuned cyclostratigraphies from Ceara Rise. In: Shackleton NJ, Curry WB, Richter C, Bralower TJ (eds) Proceedings of the Ocean Drilling Program, 154 Scientific Results. Ocean Drilling Program, pp 83-99. https://doi.org/10.2973/odp.proc. sr.154.101.1997

Backman J, Raffi I, Rio D, Fornaciari E (2012) Biozonation and biochronology of Miocene through Pleistocene calcareous nannofossils from low and middle latitudes. Newsl Stratigr 47:131-181. https://doi.org/10.1127/0078-0421/2012/0022

Balázs A, Matenco L, Magyar I, Horváth F, Cloetingh S (2016) The link between tectonics and sedimentation in back-arc basins: new genetic constraints from the analysis of the Pannonian Basin. Tectonics 35:1526-1559. https://doi.org/10.1002/2015TC004109

Baldi K (2006) Paleoceanography and climate in the Badenian (Middle Miocene, 16.4-13.0 Ma) in the Central Paratethys based on foraminifer and stable isotope evidence-abstract. Int J Earth Sci 95:119-142

Báldi K, Benkovics L, Sztanó O (2002) Badenian (Middle Miocene) basin development in SW Hungary: subsidence history based on quantitative paleobathymetry of foraminifera. Int J Earth Sci 91:490-504. https://doi.org/10.1007/s005310100226

Báldi K, Velledits F, Ćorić S, Lemberkovics V, Lőrincz K, Shevelev M (2017) Discovery of the Badenian evaporites inside the Carpathian Arc: implications for global climate change and Paratethys salinity. Geol Carpathica 68:193-206. https://doi. org/10.1515/geoca-2017-0015

Bartol M (2009) Middle Miocene calcareus nannoplankton of NE Slovenia (Western Central Paratethys). Paleontološki inštitut Ivana Rakovca ZRC SAZU, Ljubljana

Beldean C, Filipescu S, Bălc R (2010) An Early Miocene biserial foraminiferal event in the Transylvanian Basin (Romania). Geol Carpathica 61:227-234. https://doi.org/10.2478/v1009 6-010-0013-4

Beldean C, Filipescu S, Bălc R (2012) Paleoenvironmental and biostratigraphic data for the Early Miocene of the north-western Transylvanian Basin based on planktonic foraminifera. Carpathian J Earth Environ Sci 7:171-184 
Beldean C, Bercea R, Filipescu S (2013) Sedimentology and biostratigraphy of the Early-Middle Miocene transition in NW Transylvanian Basin (Pâglişa and Dej sections). Stud. Univ Babes-Bolyai Geol 58:57-70. https://doi.org/10.5038/1937-8602.58.1.5

Berner RA (1970) Sedimentary pyrite formation. Am J Sci 268:1-23

Berner RA (1984) Sedimentary pyrite formation: an update. Geochim Cosmochim Acta 48:605-615. https://doi.org/10.1016/00167037(84)90089-9

Bernhard JM, Sen Gupta BK (1999) Foraminifera of oxygen-depleted environments. In: Sen Gupta BK (ed) Modern Foraminifera. Kluwer Academic Publishers, Dordrecht, pp 141-160. https://doi. org/10.1007/0-306-48104-9_12

Bistricic A, Jenko K (1985) Transtethyan Trench "Corridor”. In: Steininger FF, Seneš J, Kleemann K, Rögl F (eds) Neogene of the Mediterranean Tethys and Paratethys. stratigraphic correlation tables and sediment distribution maps. Inst. Paleont. Vienna University, Vienna, pp 72-73

Brzobohatý R, Cicha I, Kováč M, Rögl F (2003) The Karpatian-a Lower Miocene stage of the Central Paratethys. Masaryk University, Brno

Brzobohatý R, Nolf D, Kroupa O (2007) Fish Otoliths from the Middle Miocene of Kienberg at Mikulov, Czech Republic, Vienna Basin: their paleoenvironmental and paleogeographic significance. Bull l'Institut R des Sci Nat Belqique Sci la Terre 77:167-196

Bukowski K, Sant K, Pilarz M, Kuiper K, Garecka M (2018) Radio-isotopic age and biostratigraphic position of a lower Badenian tuffite from the western Polish Carpathian Foredeep Basin (Cieszyn area). Geol Q 62:303-318. https://doi.org/10.7306/gq.1402

Chiriac M (1969) Comptes rendus des séances 4. Stratigraphie, Răspîndirea şi faciesurile Tortonianului în Dobrogea de Sud. Institut Géologique, Bucureşti

Cicha F, Rögl F (2003) Definition of the Karpatian Stage. In: The Karpatian A Lower Miocene Stage of the Central Paratethys, pp 15-26

Cita MB, Premoli Silva I (1971-1973). In: Cita MB (ed) Planktonic foraminiferal biostratigraphy of the Mediterranean Neogene. Progress in Micropaleontology, special publication Micropal. Press, The American Museum of Natural History, New York, pp 47-68

Ciulavu D, Dinu C, Szakács A, Dordea D (2000) Neogene kinematics of the Transylvanian basin (Romania). Am Assoc Pet Geol Bull 10:1589-1615

Ciupagea D, Păucă M, Ichim T (1970) Geology of the Transylvanian depression. Acad. R.S.R., Bucharest, p 256

Codarcea M, Savu H, Pavelescu M, Stancu J, Lupu D (1968) Geologic Map of Romania 1:200000 Sheet L_34_XXIV, 26 Orastie

Ćorić S, Rögl F (2004) Roggendorf-1 borehole, a key-section for Lower Badenian transgressions and the stratigraphic position of the Grund Formation (Molasse Basin, Lower Austria). Geol Carpathica 55:165-178

Ćorić S, Harzhauser M, Hohenegger J, Mandic O, Pervesler P, Roetzel R, Rögl F, Scholger R, Spezzaferri S, Stingl K, Švábenická L, Zorn I, Zuschin M (2004) Stratigraphy and correlation of the Grund Formation in the Molasse Basin, northeastern Austria (Middle Miocene, Lower Badenian). Geol Carpathica 55:207-215

Ćorić S, Pavelić D, Rögl F, Mandic O, Vrabac S (2009) Revised Middle Miocene datum for initial marine flooding of North Croatian Basins (Pannonian Basin System, Central Paratethys). Geol Croat 62:31-43

Curry WB, Shackleton NJ, Richter C, Bralower TJ (1995) Proceedings of the Ocean Drilling Program, Initial Reports 154, Initial Reports. Ocean Drilling Program, College Station

Dankers PHM, Zijderveld JDA (1981) Alternating field demagnetization of rocks, and the problem of gyromagnetic remanence. Earth Planet Sci Lett 53:89-92
Darling KF, Thomas E, Kasemann SA, Seears HA, Smart CW, Wade CM (2009) Surviving mass extinction by bridging the benthic/ planktic divide. Proc Natl Acad Sci 106:12629-12633. https:// doi.org/10.1073/pnas.0902827106

de Leeuw A (2011) Paleomagnetic and geochronologic constraints on the Miocene evolution of semi-isolated basins in southeastern Europe, PhD Thesis. Utrecht University, p 204

de Leeuw A, Bukowski K, Krijgsman W, Kuiper KF (2010) Age of the Badenian salinity crisis; impact of Miocene climate variability on the circum-Mediterranean region. Geology 38:715-718. https ://doi.org/10.1130/G30982.1

de Leeuw A, Mandic O, Krijgsman W, Kuiper K, Hrvatović H (2012) Paleomagnetic and geochronologic constraints on the geodynamic evolution of the Central Dinarides. Tectonophysics 530-531:286-298. https://doi.org/10.1016/j.tecto.2012.01.004

de Leeuw A, Filipescu S, Maţenco L, Krijgsman W, Kuiper K, Stoica M (2013) Paleomagnetic and chronostratigraphic constraints on the Middle to Late Miocene evolution of the Transylvanian Basin (Romania): implications for Central Paratethys stratigraphy and emplacement of the Tisza-Dacia plate. Glob Planet Change 103:82-98. https://doi.org/10.1016/j.glopl acha.2012.04.008

Di Stefano A, Foresi LM, Lirer F, Iaccarino SM, Turco E, Amore FO, Mazzei R, Morabito S, Salvatorini G, Abdul Aziz H (2008) Calcareous plankton high resolution bio-magnetostratigraphy for the Langhian of the Mediterranean area. Riev Ital di Paleontol e Stratigr 114:51-76

Di Stefano A, Baldassini N, Maniscalco R, Speranza F, Maffione M, Cascella A, Foresi LM (2015) New bio-magnetostratigraphic data on the Miocene Moria section (Northern Apennines, Italy): connections between the Mediterranean region and the North Atlantic Ocean. Newsl Stratigr 48:135-152

Dragoş V (1969) Contributions to the knowledge of evaporite genesis in the Transylvanian Basin. Stud şi Cercet Geol Geogr şi Geol Ser Geol 14:163-180

Filipescu S (1996) Stratigraphy of the Neogene from the Western Border of the Transylvanian Basin. Stud Univ Babes-Bolyai Geol 41:3-78

Filipescu S (2011) Cenozoic lithostratigraphic units in Transylvania. In: Bucur II, Sasaran E (eds) Calcareous algae from Romanian Carpathians-field trip guidebook. Cluj University Press, ClujNapoca, pp 1-13

Filipescu S, Beldean C (2007) Foraminifera in the Deep-Sea Environments of the Lower Hida Formation (Transylvanian Basin, Romania). Acta Palaeontol Rom 6:105-114

Filipescu S, Gîrbacea R (1997) Lower Badenian sea-level drop on the western border of the Transylvanian Basin: foraminiferal paleobathymetry and stratigraphy. Geol Carpathica 48:325-334

Filipescu S, Silye L (2008) New paratethyan biozones of planktonic foraminifera described from the Middle Miocene of the Transylvanian Basin (Romania). Geol Carpathica 59:537-544

Filipescu S, Wanek F, Miclea A, de Leeuw A, Vasiliev I (2011) Micropaleontological response to the changing environment across the Sarmatian Pannonian boundary in the Transylvanian Basin (Oarba de Mures section, Romania). Geol Carpathica 62:91-102

Fodor L, Csontos L, Bada G, Gyorfi I, Benkovics L (1999) Tertiary tectonic evolution of the Pannonian Basin system and neighbouring orogens: a new synthesis of palaeostress data. Geol Soc Lond Spec Publ 156:295-334. https://doi.org/10.1144/gsl. sp.1999.156.01.15

Foresi LM, Verducci M, Baldassini N, Lirer F, Mazzei R, Salvatorini G, Ferraro G, Da Prato S (2011) Integrated stratigraphy of St. Peter's Pool section (Malta): new age for the Upper Globigerina Limestone member and progress towards the Langhian GSSP. Stratigraphy 8:125-143 
Foresi LM, Baldassini N, Sagnotti L, Lirer F, Di Stefano A, Caricchi C, Verducci M, Salvatorini G, Mazzei R (2014) Integrated stratigraphy of the St. Thomas section (Malta Island): a reference section for the lower Burdigalian of the Mediterranean Region. Mar Micropaleontol 111:66-89. https://doi.org/10.1016/j.marmi cro.2014.06.004

Fornaciari E, Rio D (1996) Latest Oligocene to early middle Miocene quantitative calcareous nannofossil biostratigraphy in the Mediterranean region. Micropaleontology 42:1-36

Fornaciari E, Di Stefano A, Rio D, Negri A (1996) Middle Miocene quantitative calcareous nannofossil biostratigraphy in the Mediterranean region. Mar Micropaleontol 42:37-63

Goncharova IA, Il'ina LB (1997) Relations between Middle Miocene Basins of the Western and Eastern Paratethys. Stratigr Geol Correl (Stratigraha. Geol. Korrelyatsiya) 5:584-592

Gontsharova IA (1991) Tarkhanian-Karaganian cycle (Miocene) in development of Eastern Paratethys: correlation, hydrology and paleobiogeography (in Russian with English abstract). ыол Моск. о-ва испытателеи природы. отд. геол 66:4-7

Gozhyk P, Semenenko V, Andreeva-Grigorovich A, Maslun N (2015) The correlation of the Neogene of Central and Eastern Paratethys segments of Ukraine with the International Stratigraphic Chart based on planktonic microfossils. Geol Carpathica 66:235-244. https://doi.org/10.1515/geoca-2015-0022

Hall CM (2014) Direct measurement of recoil effects on ${ }^{40} \mathrm{Ar} /{ }^{39} \mathrm{Ar}$ standards. Advances in ${ }^{40} \mathrm{Ar} /{ }^{39} \mathrm{Ar}$ dating from Archaeology to Planetary Sciences. Geol Soc Lond 378:53-62. https://doi. org/10.1144/sp378.7

Hámor G (1985) Geology of the Nógrád-Cserhát area. Geologica Hungarica-Series Geologica. Margit, Deák, Budapest

Haq BU, Hardenbol J, Vail PR (1987) Chronology of fluctuating sea levels since the triassic. Science 235:1156-1167. https://doi. org/10.1126/science.235.4793.1156

Hardenbol J, Thierry J, Farley MB, Jacquin T, de Graciansky P, Vail PR (1998) Mesozoic and Cenozoic sequence chronostratigraphic framework of European basins. SEPM Spec Publ 60:3-13

Harzhauser M, Piller WE (2004) Integrated stratigraphy of the Sarmatian (Upper Middle Miocene) in the western Central Paratethys. Stratigraphy 1:65-86

Harzhauser M, Grunert P, Mandic O, Lukeneder P, Gallardo ÁG, Neubauer TA, Carnevale G, Landau BM, Sauer R, Strauss P (2018) Middle and late Badenian palaeoenvironments in the northern Vienna Basin and their potential link to the Badenian Salinity Crisis. Geol Carpathica 69:149-168. https://doi.org/10.1515/ geoca-2018-0009

Hilgen FJ, Lourens LJ, Van Dam JA (2012) The Neogene Period. In: Ogg J, Schmitz M, Ogg G (eds) The Geologic Time Scale 2012, vol 2. Elsevier, Amsterdam, pp 923-978

Hofmann K (1879) Bericht über die im östlichen Teile des Szilágyer Comitates wahrend der Sommercampagne 1878 vollführten geologischen Specialaufnahmen. Földt Közl IX:231-283

Hohenegger J, Rögl F, Ćorić S, Pervesler P, Lirer F, Roetzel R, Scholger R, Stingl K (2009) The Styrian Basin: a key to the Middle Miocene (Badenian/Langhian) Central Paratethys transgressions. Aust J Earth Sci 102

Holcová K, Doláková N, Nehyba S, Vacek F (2018) Timing of Llanghian bioevents in the Carpathian Foredeep and northern Pannonian Basin in relation to oceanographic, tectonic and climatic processes. Geol Q 62:3-17. https://doi.org/10.7306/gq.1399

Hora JM, Singer BS, Jicha BR, Beard BL, Johnson CM, de Silva S, Salisbury M (2010) Volcanic biotite-sanidine 40Ar/39Ar age discordances reflect Ar partitioning and pre-eruption closure in biotite. Geology 38:923-926. https://doi.org/10.1130/G31064.1
Horvath F, Bada G, Szafian P, Tari G, Adam A, Cloetingh S (2006) Formation and deformation of the Pannonian Basin: constraints from observational data. Geol Soc Lond Mem 32:191-206

Hryniv SP, Dolishniy BV, Khmelevska OV, Poberezhskyy AV, Vovnyuk SV (2007) Evaporites of Ukraine: a review. Geol Soc Lond Spec Publ 285:309-334. https://doi.org/10.1144/sp285.18

Hudson SM, Johnson CL, Efendiyeva MA, Rowe HD, Feyzullayev AA, Aliyev CS (2008) Stratigraphy and geochemical characterization of the Oligocene-Miocene Maikop series: implications for the paleogeography of Eastern Azerbaijan. Tectonophysics 451:40-55. https://doi.org/10.1016/j.tecto.2007.11.045

Iaccarino SM, Salvatorini G (1982) A framework of planktonic foraminifera biostratigraphy for early Miocene to Late Pliocene Mediterranean area. Paleontol Stratigr Ed Evol 2:115-125

Iaccarino SM, Premoli Silva I, Biolzi M, Foresi LM, Lirer F, Turco E, Petrizzo MR (2007) Practical manual of Neogene planktonic Foraminifera. In: Biolzi M, Iaccarino SM, Turco E, Checconi A, Rettori R (eds) International School on Planktonic Foraminifera (Neogene Planktonic Foraminifera). Tipografia Pontefelicino, Perugia

Iaccarino SM, Di Stefano A, Foresi LM, Turco E, Baldassini N, Cascella A, Da Prato S, Ferraro L, Gennari R, Hilgen FJ, Lirer F, Maniscalco R, Mazzei R, Riforgiato F, Russo B, Sagnotti L, Salvatorini G, Speranza F, Verducci M (2011) High-resolution integrated stratigraphy of the upper Burdigalian-lower Langhian in the Mediterranean: the Langhian historical stratotype and new candidate sections for defining its GSSP. Stratigraphy 8:199-215

Ilie MD (1951) Cercetări geologice in regiunea Sebeş - Sibiu - Avrig, Dări de Seamă ale Şedinţelor - Şedinţa din 27 Martie 1951. Comitetul Geologic

Ilie MD (1955) Cercetări geologice in bazinul Transilvaniei (regiunea Alba Iulia-Sibiu-Fagăraş-Rupea). In: Anularul Comite Geologic 28. Comitetul Geologic, Bucharest, pp 254-361

Ioniţă S (1962) Cîteva date noi pentru geologia regiunii Nereju-ReghiuAndreiaşu (Vrancea), Dări de Seamă ale Şedinţelor

Iorgulescu T (1951) Notă preliminară asupra datelor micropaleontologice obţinute in profilul normal V. Oltului, între Fedeleşoiu şi Râmnicu-Vâlcea, Dări de Seamă ale Şedinţelor Şedinţa din 6 Februarie 1951:58-71

Iva M, Gheorgian M, Gheorghian M (1971) Foraminifères agglutinants des couches de Hida (NW de la Transylvanie). Mém Inst Géol Géophys 14:71-102

John CM, Karner GD, Browning E, Leckie RM, Mateo Z, Carson B, Lowery C (2011) Timing and magnitude of Miocene eustasy derived from the mixed siliciclastic-carbonate stratigraphic record of the northeastern Australian margin. Earth Planet Sci Lett 304:455-467. https://doi.org/10.1016/j.epsl.2011.02.013

Juravle D-T (2010) Geologia României, Volumul II. Geologia Orogenului Carpatic. Editura STEF, Iaşi

Katz B, Richards D, Long D, Lawrence W (2000) A new look at the components of the petroleum system of the South Caspian Basin. J Pet Sci Eng 28:161-182. https://doi.org/10.1016/S0920 $-4105(00) 00076-0$

Kirschvink JL (1980) The least-squares line and plane and the analysis of palaeomagnetic data. Geophys J Int 62:699-718. https://doi. org/10.1111/j.1365-246X.1980.tb02601.x

Koch A (1900) Die Tertiärbildungen des Beckens der Siebenbürgische Landestheile. II Neogene Abtheilung. Ung. Geol. Gesellschaft, Budapest

Kollmann K (1965) Jungtertiär im steirischen Becken. Mitteilungen der Geol Gesellschaft Wien 57:479-632

Kominz MA, Browning JV, Miller KG, Sugarman PJ, Mizintseva S, Scotese CR (2008) Late Cretaceous to Miocene sea-level estimates from the New Jersey and Delaware coastal plain coreholes: 
an error analysis. Basin Res 20:211-226. https://doi.org/10.111 1/j.1365-2117.2008.00354.x

Koppers A (2002) ArArCALC F software for ${ }^{40} \mathrm{Ar} /{ }^{39} \mathrm{Ar}$ age calculations. Comput Geosci 28:605-619

Kounov A, Schmid S (2013) Fission-track constraints on the thermal and tectonic evolution of the Apuseni Mountains (Romania). Int J Earth Sci 102:207-233. https://doi.org/10.1007/s0053 1-012-0800-5

Kováč M, Andreyeva-grigorovich A, Brzobohatý R, Fodor L, Harzhauser M, Oszczypko N, Pavelic D, Rögl F, Saftic B, Sliva L, Stranik Z (2003) Karpatian paleogeography, tectonics and eustatic changes. In: The Karpatian a lower miocene stage of the central paratethys, pp 49-72

Kováč M, Baráth I, Harzhauser M, Hlavatý I, Hudáčková N (2004) Miocene depositional systems and sequence stratigraphy of the Vienna Basin Depositional systems and sequence stratigraphy. Cour Forsch Inst Senckenb 246:187-212

Kováč M, Andreyeva-grigorovich A, Bajraktarević Z, Brzobohatý R, Filipescu S, Fodor L, Harzhauser M, Nagymarosy A, Oszczypko N, Pavelić D, Rögl F, Saftić B, Sliva U, Studencka B (2007) Badenian evolution of the Central Paratethys Sea: paleogeography, climate and eustatic sea-level changes. Geol Carpathica 58:579-606

Kováč M, Hudáčková N, Halásová E, Kováčová M, Holcová K, Oszczypko-Clowes M, Báldi K, Less G, Nagymarosy A, Ruman A, Klučiar T, Jamrich M (2017a) The Central Paratethys palaeoceanography: a water circulation model based on microfossil proxies, climate, and changes of depositional environment. Acta Geol Slovaca 9:75-114

Kováč M, Márton E, Oszczypko N, Vojtko R, Hók J, Králiková S, Plašienka D, Klučiar T, Hudáčková N, Oszczypko-Clowes M (2017b) Neogene palaeogeography and basin evolution of the Western Carpathians, Northern Pannonian domain and adjoining areas. Glob Planet Change 155:133-154. https:// doi.org/10.1016/j.gloplacha.2017.07.004

Kováč M, Halásová EVA, Hudáčková N, Holcová K, Hyžný M, Jamrich M, Ruman A (2018) Towards better correlation of the Central Paratethys regional time scale with the standard geological time scale of the Miocene Epoch. Geol Carpathica 69:283-300. https://doi.org/10.1515/geoca-2018-0017

Kovačić M, Marković F, Kuiper K, Hajek-Tadesse V, Bakrac K, Derek T, Mandic O (2016) Age constraint on disintegration of the initial Pannonian Basin lake system. In: Mandic O, Pavelić D, Kovačić M, Sant K, Andrić N, Hrvatović H (eds) Field Trip Guide-Book. Lake-Basin-Evolution, RCMNS Interim Colloquium 2016. Croatian Geological Society, Zagreb, pp 19-21

Koymans MR, Langereis CG, Pastor-Galán D, van Hinsbergen DJJ (2016) Paleomagnetism.org: an online multi-platform open source environment for paleomagnetic data analysis. Comput Geosci 93:127-137. https://doi.org/10.1016/j.cageo .2016.05.007

Krézsek C, Bally AW (2006) The Transylvanian Basin (Romania) and its relation to the Carpathian fold and thrust belt: insights in gravitational salt tectonics. Mar Pet Geol 23:405-442. https:// doi.org/10.1016/j.marpetgeo.2006.03.003

Krézsek C, Filipescu S (2005) Middle to late Miocene sequence stratigraphy of the Transylvanian Basin (Romania). Tectonophysics 410:437-463. https://doi.org/10.1016/j.tecto.2005.02.018

Krézsek C, Filipescu S, Silye L, Mațenco L, Doust H (2010) Miocene facies associations and sedimentary evolution of the Southern Transylvanian Basin (Romania): implications for hydrocarbon exploration. Mar Pet Geol 27:191-214. https://doi.org/10.1016/j. marpetgeo.2009.07.009

Kuiper KF, Deino A, Hilgen FJ, Krijgsman W, Renne PR, Wijbrans JR (2008) Synchronizing rock clocks of Earth history. Science 320:500-504. https://doi.org/10.1126/science.1154339
Lee JY, Marti K, Severinghaus JP, Kawamura K, Yoo HS, Lee JB, Kim JS (2006) A redetermination of the isotopic abundances of atmospheric Ar. Geochim Cosmochim Acta 70:4507-4512. https ://doi.org/10.1016/j.gca.2006.06.1563

Liu S, Krijgsman W, Dekkers MJ, Palcu DV (2017) Early diagenetic greigite as an indicator of paleosalinity changes in the middle Miocene Paratethys Sea of Ccentral Europe. Geochem Geophys Geosyst 18:2634-2645. https://doi.org/10.1002/2016GC0066 79.Received

Lourens LJ, Hilgen FJ, Laskar J, Shackleton NJ, Wilson D (2004) The Neogene period. Geol Timescale 2004:409-440

Magyar I, Geary DH, Lantos M, Muller P, Suto-Szentai M (1999) Integrated biostratigraphic, magnetostratigraphic and chronostratigraphic correlations of the Late Miocene Lake Pannon deposits. Acta Geol Hung 42:5-31

Mandic O, de Leeuw A, Bulić J, Kuiper KF, Krijgsman W, JurišićPolšak Z (2012) Paleogeographic evolution of the Southern Pannonian Basin: ${ }^{40} \mathrm{Ar} /{ }^{39} \mathrm{Ar}$ age constraints on the Miocene continental series of Northern Croatia. Int J Earth Sci 101:1033-1046. https://doi.org/10.1007/s00531-011-0695-6

Mandic O, Rundić L, Ćorić S, Pezelj Đ, Theobalt D, Sant K, Krijgsman W (2019a) Age and mode of the middle Miocene marine flooding of the Pannonian Basin - constraints from Central Serbia. Palaios 34:71-95. https://doi.org/10.2110/palo.2018.052

Mandic O, Sant K, Kallanxhi ME, Ćorić S, Theobalt D, Grunert P, de Leeuw A, Krijgsman W (2019b) Integrated bio-magnetostratigraphy of the Badenian reference section Ugljevik in southern Pannonian Basin-implications for the Paratethys history (middle Miocene, Central Europe). Glob Planet Change 172:374-395. https://doi.org/10.1016/j.gloplacha.2018.10.010

Marinescu F, Peltz S (1967) Notă explicativă-Harta Geologică L-35VII 11. Bistriţa (1:200.000)

Martini E (1971) Standard tertiary and quaternary calcareous nannoplankton zonation. In: Farinacci A (ed) Proceedings of the second planktonic conference, Roma 1970. Edizioni Tecnoscienza 2, Rome, pp 739-785

Mărunţeanu M (1999) Litho and biostratigraphy (calcareous nannoplankton) of the Miocene deposits from the Outer Moldavides. Geol Carpathica 50:313-324

Mason PRD, Seghedi I, Szákacs A, Downes H (1998) Magmatic constraints on geodynamic models of subduction in the East Carpathians, Romania. Tectonophysics 297:157-176. https://doi. org/10.1016/S0040-1951(98)00167-X

Matenco L (2017) Tectonics and exhumation of Romanian Carpathians: inferences from kinematic and thermochronological studies. In: Rădoane M, Vespremeanu-Stroe A (eds) Landform dynamics and evolution in Romania. Springer, Bucharest, pp 15-56. https ://doi.org/10.1007/978-3-319-32589-7

Matenco L, Radivojević D (2012) On the formation and evolution of the Pannonian Basin: constraints derived from the structure of the junction area between the Carpathians and Dinarides. Tectonics 31:TC6007. https://doi.org/10.1029/2012tc003206

Matenco L, Krézsek C, Merten S, Schmid S, Cloetingh S, Andriessen P (2010) Characteristics of collisional orogens with low topographic build-up: an example from the Carpathians. Terra Nov 22:155-165. https://doi.org/10.1111/j.1365-3121.2010.00931.x

Melinte-Dobrinescu MC, Stoica M (2014) Badenian Calcareous nannofossil fluctuation in the Eastern Carpathians: palaeoenvironmental significance. Acta Palaeontol 9:23-25

Merten S (2011) Thermo-tectonic evolution of a convergent orogen with low topographic build-up: Exhumation and kinematic patterns in the Romanian Carpathians derived from thermochronology. VU Amsterdam, Amsterdam

Merten S, Matenco L, Foeken JPT, Andriessen PAM (2011) Toward understanding the post-collisional evolution of an orogen influenced by convergence at adjacent plate margins: Late 
Cretaceous-Tertiary thermotectonic history of the Apuseni Mountains. Tectonics 30:1-28. https://doi.org/10.1029/2011T $\mathrm{C} 002887$

Mészáros N (1991) Nannofossil zones in the Paleogene and Miocene deposits of the Transylvanian Basin. In: Proc. IV. INA conference. Knihovnicka ZPN, Prague, pp 87-92

Min K, Mundil R, Renne PR, Ludwig KR (2000) A test for systematic errors in 40Ar/39Ar geochronology through comparison with $\mathrm{U} / \mathrm{Pb}$ analysis of a 1.1-Ga rhyolite. Geochim Cosmochim Acta 64:73-98. https://doi.org/10.1016/S0016-7037(99)00204-5

Mirăuţa O (1967) Stratigrafia şi structura Miocenului subcarpatic din regiunea Moineşti-Tazlău. In: Dări de Seamă Ale Şedinţelor, pp 173-203

Moisescu V, Popescu G (1967) Studiul stratigrafic al formatiunilor Paleogene şi Miocene din regiunea Chinteni-Baciu-Sînpaul (nord-vestul Transilvaniei). Stud şi Cercet Geol Geofiz Geogr 12:211-224

Morley CK (2003) Models for relative motion of crustal blocks within the Carpathian region, based on restorations of the outer Carpathian thrust sheets. Tectonics 15:885-904

Mourik AA, Abels HA, Hilgen FJ, Di Stefano A, Zachariasse WJ (2011) Improved astronomical age constraints for the middle Miocene climate transition based on high-resolution stable isotope records from the central Mediterranean Maltese Islands. Paleoceanography 26:1-14. https://doi.org/10.1029/2010PA0019 81

Mullender TAT, Frederichs T, Hilgenfeldt C, de Groot LV, Fabian K, Dekkers MJ (2016) Automated paleomagnetic and rock magnetic data acquisition with an in-line horizontal " $2 \mathrm{G}$ " system. Geochem Geophys Geosyst 17:3546-3559. https://doi. org/10.1002/2016GC006436

Nagymarosy A, Hámor G (2012) Genesis and evolution of the Pannonian Basin. In: Haas J (ed) Geology of Hungary. Springer, Budapest, pp 149-200. https://doi.org/10.1016/s1574-0684(05)90048 $-8$

Nicolescu S, Mârza I (2010) The Dej Tuff of Transylvania (Romania): how old, what flavour and where from? Acta Mineral Abstr Ser IMA2010 6:684

Nigam R, Mazumder A, Henriques PJ, Saraswat R (2007) Benthic foraminifera as proxy for oxygen-depleted conditions off the Central West Coast of India. J Geol Soc India 70:1047-1054

Olteanu F (1951) Depresiunea subcarpatică în regiunile Solonţ şi Drăgugeşti (Bacău). Dări Seamă ale Şedinţelor, pp 301-312

Onstott TC, Miller ML, Ewing RC, Arnold GW, Walsh DS (1995) Recoil refinements: implications for the ${ }^{40} \mathrm{Ar} /{ }^{39} \mathrm{Ar}$ dating technique. Geochim Cosmochim Acta 59:1821-1834

Orbocea M, Manoliu E, Duitrescu D, Mitroi M (1986a) Anuarul muzeului de ştinte naturale Piatra Neamţ. In: Ciobanu M, Grasu C, Tuc I (eds) Anuarul muzeului de ştinte naturale Piatra Neamț. Muzeul de Stiinte Naturale, Piatra Neamţ, pp 51-58

Orbocea M, Manoliu E, Dumitrescu D, Mitroi M (1986b) Unele precizări biostratigrafice privind limita inferioară a depozitelor badeniene din sinclinalul Drajna (pe valea Teleajen). In: Anuarul Muzeului de Ştinte Naturale Piatra Neamţ. Piatra Neamţ, pp 51-58

Oszczypko N (1997) The Early-Middle Miocene Carpathian peripheral foreland basin (Western Carpathians, Poland). Prz Geol 45:1054-1063

Oszczypko N, Oszczypko-Clowes M (2011) Stages of development in the Polish Carpathian Foredeep basin. Cent Eur J Geosci 4:138 162. https://doi.org/10.2478/s13533-011-0044-0

Oszczypko N, Krzywiec P, Popadyuk I, Peryt T (2006) Carpathian Foredeep Basin (Poland and Ukraine): its sedimentary, structural, and geodynamic evolution. In: Golonka J, Picha FJ (eds) The Carpathians and their foreland: geology and hydrocarbon researches: AAPG Memoir 48, pp 293-350. https://doi. org/10.1306/985612m843072

Oszczypko N, Uchman A, Bubniak I (2014) The Dobrotiv Formation (Miocene) in the Boryslav-Pokuttya and Sambir nappes of the Ukrainian Carpathians: a record of sedimentary environmental change in the development of the Carpathian Foredeep Basin. Geol Q 58:393-408

Oszczypko N, Uchman A, Bubniak I (2016) The Stebnyk Formation (Miocene) in the Boryslav-Pokuttya and Sambir nappes of the Ukrainian Carpathians: a record of environmental change in the Carpathian Foredeep. Geol Q 60:473-491. https://doi. org/10.7306/gq. 1290

Palcu DV, Tulbure M, Bartol M, Kouwenhoven TJ, Krijgsman W (2015) The Badenian-Sarmatian Extinction Event in the Carpathian foredeep basin of Romania: paleogeographic changes in the Paratethys domain. Glob Planet Change 133:346-358. https ://doi.org/10.1016/j.gloplacha.2015.08.014

Palcu DV, Golovina LA, Vernyhorova YV, Popov SV, Krijgsman W (2017) Middle Miocene paleoenvironmental crises in Central Eurasia caused by changes in marine gateway configuration. Glob Planet Change 158:57-71. https://doi.org/10.1016/j.glopl acha.2017.09.013

Palcu DV, Popov SV, Golovina LA, Kuiper KF, Liu S, Krijgsman W (2019) The shutdown of an anoxic giant: magnetostratigraphic dating of the end of the Maikop Sea. Gondwana Res 67:82-100. https://doi.org/10.1016/j.gr.2018.09.011

Pálfy J, Mundil R, Renne PR, Bernor RL, Kordos L, Gasparik M (2007) U-Pb and 40Ar/39Ar dating of the Miocene fossil track site at Ipolytarnóc (Hungary) and its implications. Earth Planet Sci Lett 258:160-174. https://doi.org/10.1016/j.eps1.2007.03.029

Pälike H, Moore T, Backman J, Raffi I, Lanci L, Parés JM, Janecek T (2005) Integrated stratigraphic correlation and improved composite depth scales for ODP sites 1218 and 1219. In: Wilson PA, Lyle M, Firth JV (eds) Proceedings of the Ocean Drilling Program, 199 Scientific Results. Ocean Drilling Program, pp 1-42. https://doi.org/10.2973/odp.proc.sr.199.213.2005

Papp A, Cicha I (1978) Definition der Zeiteinheit M-Badenian. In: Papp A, Cicha I, Steininger FF (eds) M4-Badenien (Moravien, Wielicien, Kosovien). Chronostratigraphie Und Neostratotypen. Miozän Der Zentralen Paratethys. Slowakische Akademie der Wissenschaften, Bratislava, pp 47-48

Papp A, Steininger F (1974) Holostratotypus Nexing N.O. In: Papp A, Marinescu F, Senes J (eds) M5. Sarmatien. Chronostratigraphie Und Neostratotypen, Miozän Der Zentralen Paratethys, pp 162-166

Papp A, Cicha I, Senes J (1978) Gliederung des Badenien Faunenzonen und Unterstufen. In: Papp A, Cicha I, Senes J, Steininger F (eds) M4, Badenien (Moravien, Wielicien, Kosovien). Chronostratigraphie Und Neos- Tratotypen, Miozän Der Zentralen Paratethys. VEDA, Bratislava, pp 49-52

Paucă M (1951) Cercetări geologice în basinele neogene din nordvestul Ardealului, Dări de Seamă ale Şedinţelor-Şedinţa din 20 Martie 1951, pp 155-160

Paucă M (1976) Stratigrafia Miocenului marin pe bază de criterii noi. In: Podoleanu C (ed) Anuarul Muzeului de Ştiințe Naturale Piatra Neamţ Lll. Muzeul de Ştiinţe Naturale Piatra Neamţ, Piatra Neamţ, pp 121-146

Pavelić D, Kovačić M (2018) Sedimentology and stratigraphy of the Neogene rift-type North Croatian Basin (Pannonian Basin System, Croatia): a review. Mar Pet Geol 91:455-469. https://doi. org/10.1016/j.marpetgeo.2018.01.026

Pécskay Z, Lexa J, Szakács A, Seghedi I, Balogh K, Konečný V, Zelenka T, Kovacs M, Póka T, Fülöp A, Márton E, Panaiotu C, Cvetković V (2006) Geochronology of Neogene magmatism in the Carpathian arc and intra-Carpathian area. Geol Carpathica 57:511-530 
Peryt TM (2000) Resedimentation of basin centre sulphate deposits: middle Miocene Badenian of Carpathian Foredeep, southern Poland. Sediment Geol 134:331-342

Peryt TM (2006) The beginning, development and termination of the Middle Miocene Badenian salinity crisis in Central Paratethys. Sediment Geol 188-189:379-396. https://doi.org/10.1016/j. sedgeo.2006.03.014

Pezelj Đ, Mandic O, Ćorić S (2013) Paleoenvironmental dynamics in the southern Pannonian Basin during initial Middle Miocene marine flooding. Geol Carpathica 64:81-100. https://doi. org/10.2478/geoca-2013-0006

Piller WE, Harzhauser M, Mandic O (2007) Miocene Central Paratethys stratigraphy-current status and future directions. Stratigraphy 4:151-168

Pishvanova LS (1969) Stratigraphical and facial distribution of foraminifera in Miocene deposits of the western part of of Ukrainian SSR. Ann la société géologique Pologne, pp 335-350

Pop E (1951) Basinul neogen al Carausebeşului intre Poarta şi Caransebeş, Dări de Seamă ale Şedinţelor-Şedinţa din 18 Mai 1951, pp 298-301

Popescu G (1970) Planktonic Foraminiferal Zonation în the Dej Tuff Complex. Rev Roum Geol Geof Geogr Ser Geol 14:189-203

Popescu GC (1975) Études des foraminiferes du Miocene inferieur et moyen du nord-ouest de la Transylvanie. Mem Inst Géol Géophys 23:121

Popescu G, Brotea D (1994) Evolution of the Transylvanian foraminiferal assemblages during Late Oligocene and Middle Miocene. In: Nicorici E, Petrescu I, Mészáros N, Bedelean I (eds) The Miocene from the Transylvanian Basin. Romania, Cluj-Napoca, pp 119-124

Popov SV, Rögl F, Rozanov AY, Steininger FF, Shcherba IG, Kovac M (2004) Lithological-paleogeographic maps of paratethys. In: CFS Courier Forschungsinstitut Senckenberg, pp 1-46

Püspöki Z, Hámor-vidó M, Pummer T, Sári K, Lendvay P, Selmeczi I, Detzky G (2017) A sequence stratigraphic investigation of a Miocene formation supported by coal seam quality parameterscentral Paratethys, N-Hungary. Int J Coal Geol 179:196-210. https://doi.org/10.1016/j.coal.2017.05.016

Rabagia T, Maţenco L (1999) Tertiary tectonic and sedimentological evolution of the South Carpathians foredeep: tectonic vs eustatic control. Mar Pet Geol 16:719-740. https://doi.org/10.1016/ S0264-8172(99)00045-8

Rado G, Ţicleanu N, Gheorghian M, Popescu A (1980) Date noi privind litobiostratigrafia depozitelor miocenului şi pliocenului din regiunea Comăneşti-Lueta-Mărtiniş (jud. Harghita). Stud şi Cercet Geol Geofiz Geogr Geol 25:95-108

Reiser MK, Schuster R, Spikings R, Tropper P, Fügenschuh B (2017) From nappe stacking to exhumation: cretaceous tectonics in the Apuseni Mountains (Romania). Int J Earth Sci 106:659-685. https://doi.org/10.1007/s00531-016-1335-y

Rickard D, Luther GW (2007) Chemistry of iron sulfides. Chem Rev 107:514-562. https://doi.org/10.1021/cr0503658

Rijavec L (1985) Transtethyan Trench “Corridor". In: Steininger FF, Seneš J, Kleemann K, Rögl F (eds) Neogene of the Mediterranean Tethys and Paratethys. Stratigraphic correlation tables and sediment distribution maps. Inst. Paleont. Vienna University, Vienna, pp 73-74

Rögl F (1998) Palaeogeographic Considerations for Mediterranean and Paratethys Seaways (Oligocene to Miocene). Ann. des Naturhistorischen Museums Wien 99:279-310

Rögl F, Carie S, Hock GD, Harzhauser M, Mandie O, Svabenicka L, Zorn I (2002a) Correlation of the Karpatian Stage. In: Brzobohatý R, Cicha I, Kovác M, Rögl F (eds) The Karpatian-a Lower Miocene Stage of the Central Paratethys (Masaryk University). Brno The Karpatian A Lower Miocene Stage of the Central Paratethys, pp 27-34
Rögl F, Spezzaferri S, Carre S (2002b) Micropaleontology and biostratigraphy of the Karpatian-Badenian transition (EarlyMiddle Miocene boundary) in Austria (Central Para tethys). Cour Forsch Inst Senckenb 237:47-67

Rögl F, Ćorić S, Daxner-Höck H, Harzhauser M, Mandic O, Svábenická L, Zorn I (2003) Correlation of the Karpatian Stage. In: Brzobohatý R, Cicha I, Kovác M, Rögl F (eds) The Karpatian-a Lower Miocene Stage of the Central Paratethys. Masaryk University, Brno, pp 32-37

Roşca L (1951) Comunicare preliminară asupra cercetărilor geologice şi petrografice din regiunea munţilor Semenie de Nord, Dări de Seamă ale Şedinţelor-Şedinţa din 16 Martie 1951

Roure F, Roca E, Sassi W (1993) The Neogene evolution of the outer Carpathian flysch units (Poland, Ukraine and Romania): kinematics of a foreland/fold-and-thrust belt system. Sediment Geol 86:177-201. https://doi.org/10.1016/0037-0738(93)90139-V

Rusu A, Popescu G, Melinte M (1996) Oligocene-Miocene transition and main geological events in Romania. Rom J Stratigr 76:56

Sachsenhofer RF, Popov SV, Akhmetiev MA, Bechtel A, Gratzer R, Groß D, Horsfield B, Rachetti A, Rupprecht B, Schaffar WBH, Zaporozhets NI (2017) The type section of the Maikop Group (Oligocene-lower Miocene) at the Belaya River (North Caucasus): depositional environment and hydrocarbon potential. Am Assoc Pet Geol Bull 101:289-319. https://doi.org/10.1306/08051 616027

Sahy D, Condon DJ, Terry DO, Fischer AU, Kuiper KF (2015) Synchronizing terrestrial and marine records of environmental change across the Eocene-Oligocene transition. Earth Planet Sci Lett 427:171-182. https://doi.org/10.1016/j.epsl.2015.06.057

Săndulescu M (1988) Les problemes tectoniques de la courbure interne des Carpathes roumaines. Inst Geol Geof 72-73:280-300

Săndulescu M, Micu M, Popescu B (1980) La structure et la paleogeographie des formations Miocenes des Subcarpates Moldaves, pp 184-197. https://www.researchgate.net/publication/317719490

Săndulescu M, Mărunţeanu M, Popescu G (1995) Lower-Middle Miocene formations in the folded area of the East Carpathians. Rom J Stratigr 76:1-32

Sant K (2018) Changing Seas in the Miocene of Central Europe: chronostratigraphic and paleogeographic updates on Paratethys evolution. UU Dept. of Earth Sciences, Utrecht

Sant K, Palcu D, Mandic O, Krijgsman W (2017) Changing seas in the Early-Middle Miocene of Central Europe: a Mediterranean approach to Paratethyan stratigraphy. Terra Nov 29:273-281. https://doi.org/10.1111/ter.12273

Sant K, Mandic O, Rundić L, Kuiper KF, Krijgsman W (2018) Age and evolution of the Serbian Lake System: integrated results from Middle Miocene Lake Popovac. Newsl Stratigr 51:117-143. https ://doi.org/10.1127/nos/2016/0360

Sant K, Palcu DV, Turco E, Di Stefano A, Baldassini N, Kouwenhoven TJ, Kuiper KF, Krijgsman W (2019) Litho- and biostratigraphic data of lower-middle Miocene sections in the Transylvanian basin and SE Carpathian Foredeep (Romania). Data Br. https:// doi.org/10.1016/j.dib.2019.103904

Schmid SM, Bernoulli D, Fügenschuh B, Matenco L, Schefer S, Schuster R, Tischler M, Ustaszewski K (2008) The Alpine-CarpathianDinaridic orogenic system: correlation and evolution of tectonic units. Swiss J Geosci 101:139-183. https://doi.org/10.1007/ s00015-008-1247-3

Seghedi I, Szakacs A (1991) The Dej tuff from Dej-Ciceu area: some petrographical, petrochemical and volcanological aspects. Volcanic tuffs from Transylvanian Basin, Rome, pp 135-146

Seghedi I, Downes H, Szakacs A, Mason PRD, Thirlwall MF, Emilian R, Pecskay Z, Marton E, Panaiotu C (2004) Neogene-Quaternary magmatism and geodynamics in the Carpathian-Pannonian region: a synthesis. Lithos 72:117-146. https://doi.org/10.1016/j. lithos.2003.08.006 
Selmeczi I, Lantos M, Bohn-Havas M, Nagymarosy A, Szegő É (2012) Correlation of bio- and magnetostratigraphy of Badenian sequences from western and northern Hungary. Geol Carpathica 63:219-232. https://doi.org/10.2478/v10096-012-0019-1

Simon D, Palcu D, Meijer P, Krijgsman W (2018) The sensitivity of middle Miocene paleoenvironments to changing marine gateways in Central Europe. Geology 47:35-38. https://doi.org/10.1130/ G45698.1

Smart CW, Thomas E (2006) The enigma of early Miocene biserial planktic foraminifer. Geology 34:1041-1044. https://doi. org/10.1130/G23038A.1

Smart CW, Thomas E (2007) Emendation of the genus StreptochilusBrönnimann and Resig 1971 (Foraminifera) and new species from the lower Miocene of the Atlantic and Indian Oceans. Micropaleontology 53:73-103

Spezzaferri S, Ćorić S, Stingl K (2009) Palaeoenvironmental reconstruction of the Karpatian-Badenian (Late Burdigalian-Early Langhian) transition in the Central Paratethys. A case study from the Wagna section (Austria). Acta Geol Pol 4:523-544

Ştefănescu M, Mărunteanu M (1980) The age of Doftana Molasse. D.S. Inst. Geol. Geofiz. LXV, pp 169-182

Stefanescu M, Dicea O, Butac A, Ciulavu D (2006) Hydrocarbon Geology of the Romanian Carpathians, their foreland, and the Transylvanian Basin. In: Golonka J, Picha FJ (eds) The Carpathians and Their Foreland: Geology and Hydrocarbon Researches: AAPG Memoir 84. AAPG Memoir, pp 521-567. https://doi. org/10.1306/985619m843077

Stoica C, Gherasie I (1981) Halite, potassium and magnesium salts of Romania (in Romanian), Ed. Tehnica, p 247

Szabó C, Harangi S, Csontos L (1992) Review of Neogene and Quaternary volcanism of the Carpathian-Pannonian region. Tectonophysics 208:243-256. https://doi.org/10.1016/00401951(92)90347-9

Szakács A, Pécskay Z, Silye L, Balogh K, Vlad D, Fülöp A (2012) On the age of the Dej Tuff, Transylvanian Basin (Romania). Geol Carpathica 63:139-148. https://doi.org/10.2478/v1009 6-012-0011-9

Székely SF, Filipescu S (2016) Biostratigraphy and paleoenvironments of the Late Oligocene in the north-western Transylvanian Basin revealed by the foraminifera assemblages. Palaeogeogr Palaeoclimatol Palaeoecol 449:484-509. https://doi.org/10.1016/j.palae o.2016.02.043

Székely SF, Beldean C, Bindiu R, Filipescu S, Săsăran E (2016) Palaeoenvironmental changes in the Transylvanian Basin during the early Miocene revealed by the foraminifera assemblages. Geol Q 60:165-178. https://doi.org/10.7306/gq.1245

Székely S-F, Bindiu-Haitonic R, Filipescu S, Bercea R (2017) Biostratigraphy and paleoenvironmental reconstruction of the marine lower Miocene Chechiș Formation in the Transylvanian Basin based on foraminiferal assemblages. Carnets Géologie Notebooks Geol 17:11-37. https://doi.org/10.4267/2042/62041

Tărăpoancă M (2003) Architecture of the Focşani Depression: a 13 km deep basin in the Carpathians bend zone (Romania). Tectonics 22:1074. https://doi.org/10.1029/2002TC001486

Tari G, Horváth F, Rumpler J (1992) Styles of extension in the Pannonian Basin. Tectonophysics 208:203-219. https://doi. org/10.1016/0040-1951(92)90345-7

ter Borgh M, Vasiliev I, Stoica M, Knežević S, Matenco L, Krijgsman W, Rundić L, Cloetingh S (2013) The isolation of the Pannonian basin (Central Paratethys): new constraints from magnetostratigraphy and biostratigraphy. Glob Planet Change 103:99-118. https://doi.org/10.1016/j.gloplacha.2012.10.001

Tiliţă M, Matenco L, Dinu C, Ionescu L, Cloetingh S (2013) Understanding the kinematic evolution and genesis of a back-arc continental "sag" basin: the Neogene evolution of the Transylvanian Basin. Tectonophysics 602:237-258. https://doi.org/10.1016/j. tecto.2012.12.029

Tischler M (2005) A combined structural and sedimentological study of the Inner Carpathians at the northern rim of the Transylvanian basin (N. Romania). Philos. Fak

Tischler M, Matenco L, Filipescu S, Groger HR, Wetzel A, Fugenschuh B (2008) Tectonics and sedimentation during convergence of the ALCAPA and Tisza-Dacia continental blocks: the Pienide nappe emplacement and its foredeep (N. Romania). Geol Soc Lond Spec Publ 298:317-334. https://doi.org/10.1144/sp298.15

Túnyi I, Vass D, Karoli S, Janocko J, Halásová E, Zlínská A, Belácek B (2005) Magnetostratigraphy of Badenian evaporite deposits (East Slovak Basin). Geol Carpathica 56:273-284

Turco E, Bambini AM, Foresi L, Iaccarino S, Lirer F, Mazzei R, Salvatorini G (2002) Middle Miocene High-resolution calcareous plankton biostratigraphy at Site 926 (Leg 154, Equatorial Atlantic Ocean): paleoecological and paleobiogeographical implications. Geobios Mem Spec 34:257-276

Turco E, Hüsing S, Hilgen F, Cascella A, Gennari R, Iaccarino SM, Sagnotti L (2017) Astronomical tuning of the La Vedova section between 16.3 and 15.0 Ma. Implications for the origin of megabeds and the Langhian GSSP. Newsl Stratigr 50:1-29. https:// doi.org/10.1127/nos/2016/0302

Turner G, Cadogan PH (1974) Possible effects of ${ }^{39} \mathrm{Ar}$ recoil in ${ }^{40} \mathrm{Ar}$ ${ }^{39}$ Ar dating. Proc Fifth Lunar Sci Conf 2:1601-1615

Ustaszewski K, Schmid SM, Fügenschuh B, Tischler M, Kissling E, Spakman W (2008) A map-view restoration of the Alpine-Carpathian-Dinaridic system for the Early Miocene. Swiss J Geosci 101:273-294. https://doi.org/10.1007/s00015-008-1288-7

Vasiliev I, de Leeuw A, Filipescu S, Krijgsman W, Kuiper K, Stoica M, Briceag A (2010) The age of the Sarmatian-Pannonian transition in the Transylvanian Basin (Central Paratethys). Palaeogeogr Palaeoclimatol Palaeoecol 297:54-69. https://doi.org/10.1016/j. palaeo.2010.07.015

Vass D (2002a) Lithostratigraphy of Western Carpathians: Neogene and Buda Paleogene. In: Kaličiak M (eds) Śtátny geologický ústav Dionýza Štúra, Bratislava, p 202

Vass D (2002b) The origin and disappearance of the Hungarian Paleogene Basins and the Short Term Lower Miocene Basins in the Northern Hungary and Southern Slovakia. Bull l'Academie Serbe des Sci des Arts 125:29-46

Wade BS, Pearson PN, Berggren WA, Pälike H (2011) Review and revision of Cenozoic tropical planktonic foraminiferal biostratigraphy and calibration to the geomagnetic polarity and astronomical time scale. Earth Sci Rev 104:111-142. https://doi. org/10.1016/j.earscirev.2010.09.003

Zachos J, Pagani M, Sloan L, Thomas E, Billups K (2001) Trends, rhythms, and aberrations in global climate $65 \mathrm{Ma}$ to present. Science 292:686-693. https://doi.org/10.1126/science.1059412

Zijderveld JDA (1967) Demagnetization of rocks: analysis of results. In: Collinson DW, Creer KM, Runcom SK (eds) Methods in paleomagnetism. Elsevier, Amsterdam, pp 254-286

Zuschin M, Harzhauser M, Hengst B, Mandic O, Roetzel R (2014) Long-term ecosystem stability in an Early Miocene estuary. Geology 42:7-10. https://doi.org/10.1130/G34761.1 